\title{
Soil trace gas fluxes along orthogonal precipitation and soil fertility gradients in tropical lowland forests of Panama
}

\author{
Amanda L. Matson ${ }^{1, *}$, Marife D. Corre ${ }^{1, *}$, Kerstin Langs ${ }^{1}$, and Edzo Veldkamp ${ }^{1}$ \\ ${ }^{1}$ Soil Science of Tropical and Subtropical Ecosystems, University of Goettingen, \\ Buesgenweg 2, 37077 Goettingen, Germany \\ *These authors contributed equally to this work.
}

Correspondence to: Amanda L. Matson (amanda.matson@ scionresearch.com)

Received: 14 September 2016 - Discussion started: 24 November 2016

Revised: 7 June 2017 - Accepted: 9 June 2017 - Published: 26 July 2017

\begin{abstract}
Tropical lowland forest soils are significant sources and sinks of trace gases. In order to model soil trace gas flux for future climate scenarios, it is necessary to be able to predict changes in soil trace gas fluxes along natural gradients of soil fertility and climatic characteristics. We quantified trace gas fluxes in lowland forest soils at five locations in Panama, which encompassed orthogonal precipitation and soil fertility gradients. Soil trace gas fluxes were measured monthly for $1(\mathrm{NO})$ or $2\left(\mathrm{CO}_{2}, \mathrm{CH}_{4}, \mathrm{~N}_{2} \mathrm{O}\right)$ years (2010-2012) using vented dynamic (for NO only) or static chambers with permanent bases. Across the five sites, annual fluxes ranged from 8.0 to $10.2 \mathrm{Mg} \mathrm{CO}_{2}-\mathrm{C},-2.0$ to $-0.3 \mathrm{~kg}$ $\mathrm{CH}_{4}-\mathrm{C}, 0.4$ to $1.3 \mathrm{~kg} \mathrm{~N}_{2} \mathrm{O}-\mathrm{N}$ and -0.82 to $-0.03 \mathrm{~kg}$ NO$\mathrm{N} \mathrm{ha}^{-1} \mathrm{yr}^{-1}$. Soil $\mathrm{CO}_{2}$ emissions did not differ across sites, but they did exhibit clear seasonal differences and a parabolic pattern with soil moisture across sites. All sites were $\mathrm{CH}_{4}$ sinks; within-site fluxes were largely controlled by soil moisture, whereas fluxes across sites were positively correlated with an integrated index of soil fertility. Soil $\mathrm{N}_{2} \mathrm{O}$ fluxes were low throughout the measurement years, but the highest emissions occurred at a mid-precipitation site with high soil $\mathrm{N}$ availability. Net negative NO fluxes at the soil surface occurred at all sites, with the most negative fluxes at the low-precipitation site closest to Panama City; this was likely due to high ambient NO concentrations from anthropogenic sources. Our study highlights the importance of both shortterm (climatic) and long-term (soil and site characteristics) factors in predicting soil trace gas fluxes.
\end{abstract}

\section{Introduction}

Soils can be both sources and sinks of carbon dioxide $\left(\mathrm{CO}_{2}\right)$, methane $\left(\mathrm{CH}_{4}\right)$, nitrous oxide $\left(\mathrm{N}_{2} \mathrm{O}\right)$ and nitric oxide $(\mathrm{NO})$. Tropical forest soils, specifically, are the largest natural source of soil $\mathrm{CO}_{2}$ (Raich and Schlesinger, 1992) and $\mathrm{N}_{2} \mathrm{O}$ (Bouwman et al., 1993; Prather et al., 1995) and can be significant sinks of $\mathrm{CH}_{4}$ (Steudler et al., 1996; Keller et al., 2005; Sousa Neto et al., 2011). Although soil NO fluxes in tropical forests are often low (Keller and Reiners, 1994; Koehler et al., 2009b) and the canopy can act as a sink for a large proportion of soil-emitted NO (Rummel et al., 2002), even low emissions may be important in regulating atmospheric oxidant production (Keller et al., 1991; Chameides et al., 1992). However, annual soil trace gas fluxes in Central and South American (CSA) tropical lowland forests can vary significantly; in one study, $\mathrm{N}_{2} \mathrm{O}$ emissions varied by 1 order of magnitude (1.23 to $11.39 \mathrm{~kg} \mathrm{Nha}^{-1} \mathrm{yr}^{-1}$; Silver et al., 2005). Such disparity in measurements, caused by the temporal and spatial variability found in tropical forests (Townsend et al., 2008), makes it challenging to model soil trace gas fluxes from these areas and to predict how they might be affected by climate change.

Temporal variations in soil trace gas fluxes are primarily correlated with temperature and moisture. Temperature is often more important where there are annual extremes in temperature, such as in temperate and boreal regions, whereas precipitation and soil moisture are more important in tropical regions where air temperature does not vary much throughout the year (Saikawa et al., 2013). Soil moisture affects microbial activity both directly through water availability and 
indirectly through its influence on the soil oxygen status and gas diffusivity (Davidson and Schimel, 1995). Spatial variations in soil trace gas fluxes are largely controlled by soil characteristics. Soil texture, for example, strongly influences soil water retention and gas diffusivity (Koehler et al., 2010; Hassler et al., 2015) as well as soil fertility, plant productivity, decomposition and ultimately soil nutrient availability (Silver et al., 2000; Sotta et al., 2008; Allen et al., 2015).

Soil $\mathrm{CO}_{2}$ fluxes at the soil surface are the result of interacting belowground processes, including autotrophic (root) respiration and heterotrophic (microbes and soil fauna) respiration (Raich and Schlesinger, 1992; Hanson et al., 2000). Although temporal and spatial drivers may affect these processes differently, the net response of soil $\mathrm{CO}_{2}$ fluxes shows some consistent trends. Soil $\mathrm{CO}_{2}$ emissions from CSA tropical forest soils generally exhibit positive relationships with soil temperature (Chambers et al., 2004; Schwendenmann and Veldkamp, 2006; Sotta et al., 2006; Koehler et al., 2009a) and soil moisture (Davidson et al., 2000). The relationship between $\mathrm{CO}_{2}$ and moisture is often parabolic, with emissions increasing until the threshold at which anaerobic conditions start to inhibit soil $\mathrm{CO}_{2}$ production and/or gas diffusion and then decreasing (Schwendenmann et al., 2003; Sotta et al., 2006; Koehler et al., 2009a). Spatial differences in soil $\mathrm{CO}_{2}$ emissions can be affected by soil characteristics. Both Silver et al. (2005) and Sotta et al. (2006) noted a soil texture effect on net soil $\mathrm{CO}_{2}$ emissions; higher emissions occurred in sandy compared to clayey Ferralsol soils, which were attributed to respiration from the higher fine-root biomass in the sandy soils. Soil fertility can also affect net soil $\mathrm{CO}_{2}$ emissions; Schwendenmann et al. (2003) observed a positive relationship between soil $\mathrm{CO}_{2}$ flux and spatial differences in soil organic $\mathrm{C}$ and total $\mathrm{N}$, and a negative relationship with soil total $\mathrm{P}$ (possibly due to lower fine-root biomass in areas of high $\mathrm{P}$ ).

Soil $\mathrm{CH}_{4}$ fluxes reflect the combined activity of methanotrophs $\left(\mathrm{CH}_{4}\right.$ consumers $)$ and methanogens $\left(\mathrm{CH}_{4}\right.$ producers), the ratio of which can change in space and time. Since the activity of both functional groups can increase with temperature (Conrad, 1996; Chin et al., 1999; Mohanty et al., 2007), net changes in soil $\mathrm{CH}_{4}$ fluxes in response to temperature are more likely to be driven by other site conditions, such as soil moisture. Soil $\mathrm{CH}_{4}$ fluxes (predominant flux indicated by positive values, representing net emissions, or negative values, representing net consumption) in CSA tropical lowland forests often exhibit positive correlations with soil moisture (Keller and Reiners, 1994; Verchot et al., 2000; Davidson et al., 2004; Veldkamp et al., 2013) since high soil moisture conditions favor $\mathrm{CH}_{4}$ production. In most soils, $\mathrm{CH}_{4}$ consumption is reduced due to inhibited diffusion of $\mathrm{CH}_{4}$ from the atmosphere to the soil (Le Mer and Roger, 2001; Koehler et al., 2012; Veldkamp et al., 2013). Although they have less often been the focus of $\mathrm{CH}_{4}$ studies, soil biochemical characteristics (i.e., soil fertility status) may also play an important role. Veldkamp et al. (2013) reported that increases in soil $\mathrm{N}$ availability stimulate $\mathrm{CH}_{4}$ uptake and/or reduce $\mathrm{CH}_{4}$ production in soil, and Hassler et al. (2015) also showed that soil fertility (i.e., increased soil $\mathrm{N}$ availability and decreased soil exchangeable $\mathrm{Al}$ ) enhances soil $\mathrm{CH}_{4}$ uptake.

$\mathrm{N}$-oxide gases $\left(\mathrm{N}_{2} \mathrm{O}\right.$ and $\left.\mathrm{NO}\right)$ are produced and consumed through the microbial processes of nitrification and denitrification (Chapuis-Lardy et al., 2007). In general, soil NO production through nitrification dominates in aerobic conditions, whereas soil $\mathrm{N}_{2} \mathrm{O}$ production through denitrification dominates in anaerobic conditions (Conrad, 2002). Therefore, as shown in several CSA tropical forest studies (Keller and Reiners, 1994; Verchot et al., 1999; Davidson et al., 2004; Keller et al., 2005; Koehler et al., 2009b), with increases in soil moisture, soil NO fluxes generally decrease (though Gut et al. (2002) show that this relationship is complex), while soil $\mathrm{N}_{2} \mathrm{O}$ fluxes increase. Soil temperature can also be positively correlated with NO flux (Gut et al., 2002) and negatively correlated with soil $\mathrm{N}_{2} \mathrm{O}$ emissions (Keller et al., 2005), though this may be due to a co-correlation of soil temperature with soil moisture. Soil $\mathrm{N}$-oxide fluxes may also be affected by soil texture; soil $\mathrm{N}_{2} \mathrm{O}$ emissions can be stimulated by the higher soil $\mathrm{N}$ availability and greater proportion of anaerobic microsites in clayey soils (Keller et al., 2005; Silver et al., 2005; Sotta et al., 2008), whereas soil NO fluxes can be facilitated by the higher diffusivity in sandy soils (Silver et al., 2005). Finally, as an essential substrate for nitrification and denitrification, $\mathrm{N}$ availability in the soil is a primary controlling factor in soil $\mathrm{N}$-oxide fluxes (Koehler et al., 2009b; Corre et al., 2014).

Climate scenarios suggest that tropical regions may experience large changes in precipitation regimes in the future, with moist tropical regions likely experiencing both higher annual precipitation and more extreme precipitation events (Stocker et al., 2013). Such changes could significantly alter current soil trace gas fluxes, since soil moisture, as described above, plays an important role in both the temporal and spatial variability of soil trace gas fluxes. One approach to studying how changes in precipitation may alter soil trace gas fluxes is to investigate these fluxes along a natural gradient of climate (e.g., precipitation) in a localized region. This approach was used by Holtgrieve et al. (2006), on the Kula volcanic lava flow in Hawaii, to show that soil $\mathrm{N}$ cycling and $\mathrm{N}$-oxide fluxes were strongly affected by mean annual precipitation. However, as suggested by Santiago et al. (2005), precipitation gradients in continental tropical forests, where there are variations in species composition and soil parent material, may exhibit different patterns than those in Hawaii. Additionally, precipitation (or climate) is itself a soil-forming factor (Jenny, 1945), and continental tropical lowland soils are considerably older than the relatively young volcanic soils (Santiago et al., 2005). Therefore, the soils in continental precipitation gradients will reflect both the long-term effects of the precipitation regime (i.e., on differences in soil 

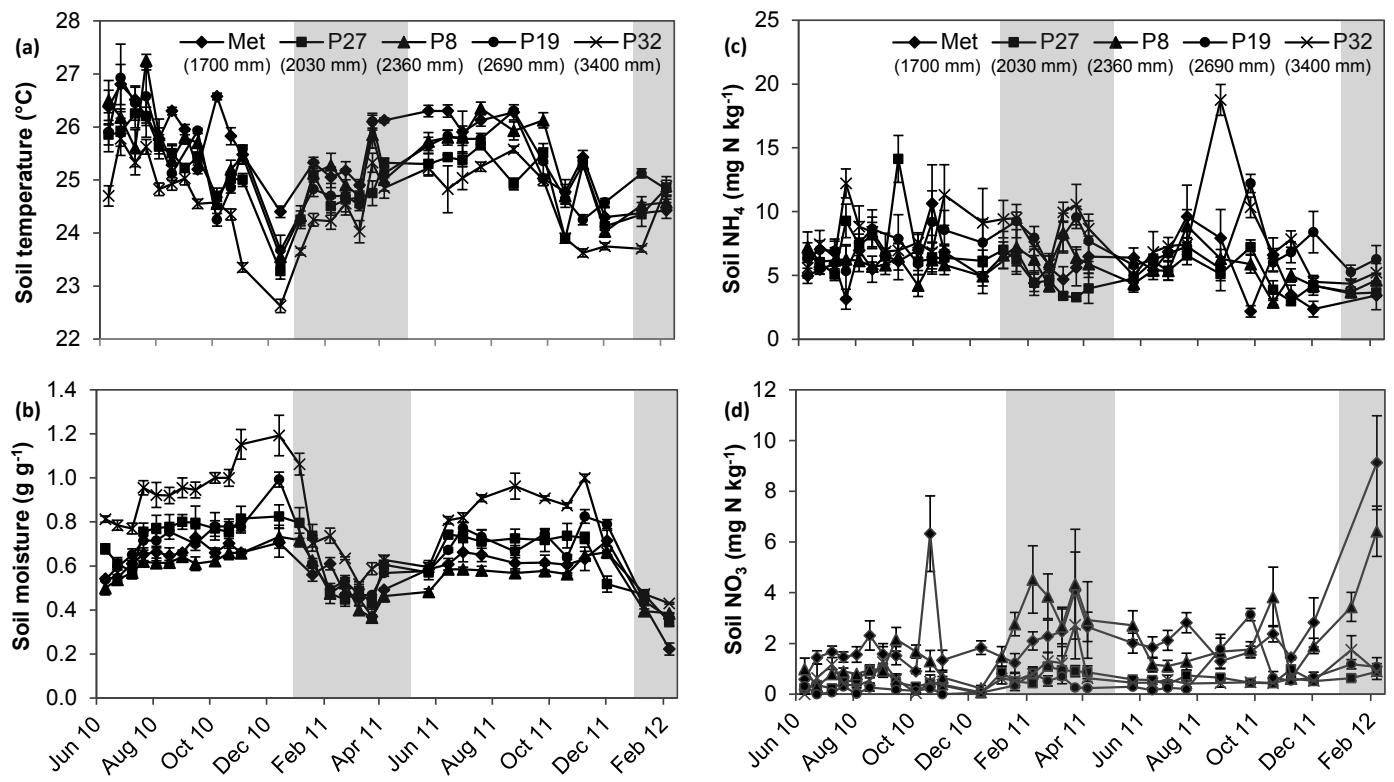

Figure 1. Mean $( \pm \mathrm{SE}, n=4)$ soil (a) temperature, (b) moisture, (c) $\mathrm{NH}_{4}^{+}$and (d) $\mathrm{NO}_{3}^{-}$concentrations measured in the top $5 \mathrm{~cm}$ of soil in lowland forests along orthogonal gradients of annual precipitation and soil fertility in the Panama Canal watershed, central Panama. The gray shading indicates the dry season (January through April).

physical and biochemical characteristics) and short-term effects (i.e., on soil moisture).

In this study, we quantified soil trace gas fluxes in tropical lowland forests of the Panama Canal watershed, spanning a precipitation gradient of $1700-3400 \mathrm{~mm} \mathrm{yr}^{-1}$ (Fig. S1 in the Supplement). Soil fertility varied orthogonally with this precipitation gradient (Fig. S2; based on an aggregate index that included clay content, ${ }^{15} \mathrm{~N}$ natural abundance, effective cation exchange capacity (ECEC), organic $C: N$ ratio and exchangeable Al; see Sect. 2.4). The objectives of our study were to (1) determine how soil fluxes of $\mathrm{CO}_{2}, \mathrm{CH}_{4}, \mathrm{~N}_{2} \mathrm{O}$ and $\mathrm{NO}$ vary along orthogonal gradients of precipitation and soil fertility and to (2) assess and compare the spatial and temporal controls of soil trace gas fluxes in lowland tropical forests. By using the orthogonal gradients of precipitation and soil fertility, we were able to examine the relative importance of climatic factors vs. soil biochemical characteristics for soil trace gas fluxes. We hypothesized that the temporal and spatial patterns of soil trace gas fluxes across sites would follow the pattern of the most important controlling soil factors: soil $\mathrm{CO}_{2}$ fluxes would be parabolic in relation to increasing soil moisture along the precipitation gradient; soil $\mathrm{CH}_{4}$ fluxes would increase (or $\mathrm{CH}_{4}$ consumption would decrease) with increasing soil moisture and decreasing soil fertility along the precipitation gradient; and soil NO fluxes would decrease, whereas soil $\mathrm{N}_{2} \mathrm{O}$ fluxes would increase with increasing soil moisture along the precipitation gradient.

\section{Methods}

\subsection{Study sites}

Soil trace gas fluxes were measured in five study sites of the Center for Tropical Forest Science (CTFS) located in the Panama Canal watershed, central Panama (Table 1; Fig. S1). Mean annual air temperature is $27^{\circ} \mathrm{C}$ (Windsor, 1990), and the soil temperature across all sites fluctuated between 22.5 and $27.5^{\circ} \mathrm{C}$ during our study years (Fig. 1a). The five sites span a gradient of annual precipitation from $1700 \mathrm{~mm} \mathrm{yr}^{-1}$ in the Metropolitan National Park (Met) on the Pacific side to $3400 \mathrm{~mm} \mathrm{yr}^{-1}$ in $\mathrm{P} 32$ on the Atlantic side; the dry season generally lasts from January through April (Corre et al., 2014). The sites were located in either old-growth (P8 and P32) or mature secondary (Met, P27, and P19) lowland forests with tree densities $(\geq 10 \mathrm{~cm}$ diameter at breast height; DBH) of 322 stems ha $^{-1}$ in Met, 395 stems ha $^{-1}$ in P27, 560 stems ha ${ }^{-1}$ in P8, 520 stems ha $^{-1}$ in P19 and 537 stems ha $^{-1}$ in P32 (Pyke et al., 2001). Since precipitation and parent materials vary across these sites, soil types also vary from Cambisols (Met and P27) on the Pacific side to Ferralsols (P8, P19 and P32) on the Atlantic side (Table 1). The floristic composition at these sites has been shown to be correlated with regional precipitation and geology and soil attributes (Pyke et al., 2001). The amounts and forms of soil organic $\mathrm{P}$ are strongly controlled by soil properties, whereas the proportion of soil organic $\mathrm{P}$ to total $\mathrm{P}$ is insensitive to the variation in rainfall and soil properties (Turner and Engelbrecht, 2011). 
Table 1. Description of location, rainfall and geology of 1 ha forest inventory plots located in the Panama Canal watershed, central Panama.

\begin{tabular}{|c|c|c|c|c|c|c|c|}
\hline Plot code ${ }^{a}$ & Longitude, latitude & $\begin{array}{l}\text { Elevation } \\
\text { (m above } \\
\text { sea level) }\end{array}$ & $\begin{array}{l}\text { Forest age } \\
\text { classification }^{\mathrm{a}}\end{array}$ & $\begin{array}{l}\text { Soil taxonomic } \\
\text { order }^{b}\end{array}$ & $\begin{array}{l}\text { Soil texture } \\
(\% \text { sand/ } \\
\text { silt/clay })^{\mathrm{c}}\end{array}$ & $\begin{array}{l}\text { Precipitation } \\
\left(\mathrm{mm} \mathrm{yr}^{-1}\right)^{\mathrm{b}}\end{array}$ & Geology $\mathrm{y}^{\mathrm{b}}$ \\
\hline Metropolitan & $79^{\circ} 33^{\prime} \mathrm{W}, 8^{\circ} 59^{\prime} \mathrm{N}$ & 30 & $\begin{array}{l}\text { Mature } \\
\text { secondary }\end{array}$ & $\begin{array}{l}\text { Inceptisol } \\
\text { (Cambisol) }\end{array}$ & $3 / 35 / 62$ & 1700 & $\begin{array}{l}\text { Agglomerate of andesitic tuff, } \\
\text { early to late Oligocene }\end{array}$ \\
\hline P27 & $79^{\circ} 38^{\prime} \mathrm{W}, 9^{\circ} 4^{\prime} \mathrm{N}$ & 160 & $\begin{array}{l}\text { Mature } \\
\text { secondary }\end{array}$ & $\begin{array}{l}\text { Inceptisol } \\
\text { (Cambisol) }\end{array}$ & $2 / 38 / 60$ & 2030 & $\begin{array}{l}\text { Agglomerate of siltstone, tuff } \\
\text { and limestone, Early Miocene }\end{array}$ \\
\hline P8 & $79^{\circ} 44^{\prime} \mathrm{W}, 9^{\circ} 10^{\prime} \mathrm{N}$ & 50 & $\begin{array}{l}\text { Old } \\
\text { growth }\end{array}$ & $\begin{array}{l}\text { Oxisol } \\
\text { (Ferralsol) }\end{array}$ & $12 / 39 / 48$ & 2360 & $\begin{array}{l}\text { Basaltic and andesitic lavas and } \\
\text { tuff, pre-Tertiary }\end{array}$ \\
\hline P19 & $79^{\circ} 46^{\prime} \mathrm{W}, 9^{\circ} 11^{\prime} \mathrm{N}$ & 160 & $\begin{array}{l}\text { Mature } \\
\text { secondary }\end{array}$ & $\begin{array}{l}\text { Oxisol } \\
\text { (Ferralsol) }\end{array}$ & $10 / 27 / 63$ & 2690 & $\begin{array}{l}\text { Basaltic and andesitic lavas and } \\
\text { tuff, pre-Tertiary }\end{array}$ \\
\hline $\mathrm{P} 32$ & $79^{\circ} 43^{\prime} \mathrm{W}, 9^{\circ} 21^{\prime} \mathrm{N}$ & 340 & $\begin{array}{l}\text { Old } \\
\text { growth }\end{array}$ & $\begin{array}{l}\text { Oxisol } \\
\text { (Ferralsol) }\end{array}$ & $1 / 39 / 60$ & 3400 & $\begin{array}{l}\text { Basaltic and andesitic lavas and } \\
\text { tuff, pre-Tertiary }\end{array}$ \\
\hline
\end{tabular}

a Plot codes and forest age classifications are from Pyke et al. (2001). ${ }^{\mathrm{b}}$ Turner and Engelbrecht (2011) reported the tentative soil order (based on US soil taxonomy with the equivalent FAO classification in brackets), mean annual precipitation (estimated from location and elevation data as described by Engelbrecht et al., 2007) and the geological information (taken from Stewart et al., 1980). ${ }^{\mathrm{c}}$ Textural analyses are the weighted average of the sampling depth intervals: $0-5,5-10,10-25$ and $25-50 \mathrm{~cm}$.

\subsection{Soil trace gas flux calculation}

Soil $\mathrm{CO}_{2}, \mathrm{CH}_{4}$ and $\mathrm{N}_{2} \mathrm{O}$ fluxes were determined every 2-4 weeks from June 2010 through February 2012 (28-31 sampling dates) using vented static chambers. Within each of the five sites, a $20 \mathrm{~m}$ grid was placed over a 1 ha area and we randomly chose four $20 \times 20 \mathrm{~m}$ replicate plots with a minimum distance of $20 \mathrm{~m}$ between plots. In each replicate plot, four permanent chamber bases were installed $\left(0.04 \mathrm{~m}^{2}\right.$ in area and $0.25 \mathrm{~m}$ in height after inserting $2 \mathrm{~cm}$ into the soil) at the ends of two perpendicular $20 \mathrm{~m}$ transects that crossed in the plot center. The total volume of the chamber (with cover) was $11 \mathrm{~L}$. To determine soil trace gas fluxes, chamber covers were placed on the bases and gas samples $(100 \mathrm{~mL})$ were taken 2, 12, 22 and 32 min later. Samples were stored in pre-evacuated glass containers with Teflon-coated stopcocks. At the Gamboa field laboratory, gas samples were then analyzed for $\mathrm{CO}_{2}, \mathrm{CH}_{4}$ and $\mathrm{N}_{2} \mathrm{O}$ concentrations using a gas chromatograph (Shimadzu GC-14B; Columbia, MD, USA) equipped with a flame ionization detector (FID), an electron capture detector (ECD) and an autosampler; this is the same instrument that was used in our earlier studies (Koehler et al., 2009a, b, 2010, 2012; Veldkamp et al., 2013; Corre et al., 2014). The instrument detection limits were $50 \mathrm{ppm} \mathrm{CO}_{2}$, 43 ppb $\mathrm{N}_{2} \mathrm{O}$ and $45 \mathrm{ppb} \mathrm{CH}_{4}$. Gas concentrations were measured by comparing integration peaks with those of three or four standard gases containing increasing concentrations of $\mathrm{CO}_{2}, \mathrm{CH}_{4}$ and $\mathrm{N}_{2} \mathrm{O}$ (Deuste Steininger $\mathrm{GmbH}$, Mühlhausen, Germany).

Soil NO fluxes were determined every $2-4$ weeks from June 2010 through June 2011 (18-21 sampling dates) using vented dynamic chambers (11 L volume) placed for 5-7 min on the same permanent bases described above. The NO ambient mixing ratio was measured at a height of $2 \mathrm{~m}$ above the ground (prior to each chamber measurement) near each of the four chamber locations at each of the four replicate plots per site on each sampling day. To measure NO, the air from the chamber (ambient air) was sampled by a pump with a flow rate of $0.5-0.6 \mathrm{~L} \mathrm{~min}^{-1}$, passed through a $\mathrm{CrO}_{3}$ catalyst that oxidizes $\mathrm{NO}$ to $\mathrm{NO}_{2}$ and flowed across a fabric wick saturated with a luminol solution. The luminol then oxidizes and produces chemiluminescence, which is proportional to the concentration of $\mathrm{NO}_{2}$ and is measured with a Scintrex LMA3 chemiluminescence detector (Unisearch, Ontario, Canada). To minimize deposition losses within the sampling system, all parts in contact with the sample gas are made of Teflon (PTFE). To prevent contamination of the tubing and analyzers, particulate matter is removed from the sampled air by PTFE particulate filters (pore size $5 \mu \mathrm{m}$ ). In order to minimize potential changes in catalyst efficiency caused by variations in air humidity, a known flux of ambient air dried with silica gel was mixed with the sampled air to maintain a humidity of $\sim 50 \%$; the detector was also calibrated in situ prior to and following the chamber measurements using a standard gas (3000 ppb NO; Deuste Steininger GmbH, Mühlhausen, Germany). The instrument detection limit was $0.04 \mathrm{ppb} \mathrm{NO} / \mathrm{mV}$; $\mathrm{mV}$ is the electrical signal from the produced chemiluminescence.

Soil trace gas fluxes were calculated as the linear change in concentration over time and were adjusted for air temperature and atmospheric pressure measured during or directly after sampling. To calculate soil NO fluxes, we considered the first $3 \mathrm{~min}$ of linear change in $\mathrm{NO}$ concentrations with chamber closure time. For $\mathrm{CO}_{2}, \mathrm{~N}_{2} \mathrm{O}$ and $\mathrm{CH}_{4}$ fluxes, all three gases were analyzed in our gas chromatograph sequentially from the same gas sample. Thus, we based our best fit of gas concentration vs. time on the $\mathrm{CO}_{2}$ concentration increase, as it is the gas with the highest concentration among these three gases. We did not observe any evidence of ebullition (e.g., a sudden increase in gas concentration during our 30 min chamber closure), and the $\mathrm{CO}_{2}$ concentration always increased linearly with time of chamber closure, so a linear fit was used for all three gases. Zero fluxes and negative fluxes (i.e., for $\mathrm{N}_{2} \mathrm{O}$ and $\mathrm{CH}_{4}$ ) were all included in our data analysis. 
Annual soil NO fluxes were calculated using the June 2010 to May 2011 measurements, and annual soil $\mathrm{CO}_{2}$ and $\mathrm{N}_{2} \mathrm{O}$ fluxes were calculated using the January to December 2011 measurements; annual fluxes were calculated using the trapezoid rule, assuming a linear relationship in fluxes between sampling days (Koehler et al., 2009a, b, 2010; Veldkamp et al., 2013; Corre et al., 2014).

\subsection{Soil biochemical characteristics}

In each replicate plot after each soil trace gas flux measurement, samples of the top $5 \mathrm{~cm}$ of soil were taken about $1 \mathrm{~m}$ from each of the four chamber bases, pooled and mixed thoroughly in the field to measure soil extractable $\mathrm{NH}_{4}^{+}$and $\mathrm{NO}_{3}^{-}$ concentrations and gravimetric water content. In the field, soil samples were placed into prepared extraction bottles containing $150 \mathrm{~mL}$ of $0.5 \mathrm{M} \mathrm{K}_{2} \mathrm{SO}_{4}$ and shaken thoroughly. Back at the field station ( $\leq 6 \mathrm{~h}$ after the samples were taken), the extraction bottles were again shaken $(\sim 1 \mathrm{~h})$ and then the extracts were filtered and frozen immediately. The remaining soil was oven dried at $105^{\circ} \mathrm{C}$ for 1 day in order to ascertain gravimetric water content; this was then used to calculate the dry mass of the soil that had been extracted for mineral $\mathrm{N}$. The frozen extracts were sent by air to the University of Göttingen, Germany for analysis by continuous flow injection colorimetry (Cenco/Skalar Instruments, Breda, the Netherlands). The Berthelot reaction method was used to determine $\mathrm{NH}_{4}^{+}$(Skalar Method 155-000) and the copper-cadmium reduction method was used to determine $\mathrm{NO}_{3}^{-}\left(\mathrm{NH}_{4} \mathrm{Cl}\right.$ buffer without ethylenediaminetetraacetic acid; Skalar Method 461000).

Soil pits were dug in the center of each of the four replicate plots per site and soil samples were taken at depth intervals of $0-5,5-10,10-25$ and $25-50 \mathrm{~cm}$. Soil samples were air dried and sieved through a $2 \mathrm{~mm}$ sieve. Natural abundance ${ }^{15} \mathrm{~N}$ signatures were determined from the ground soil samples using isotope ratio mass spectrometry (IRMS; Delta Plus; Finnigan MAT, Bremen, Germany). We calculated the $\delta^{15} \mathrm{~N}$ enrichment factor $(\varepsilon)$ using the Rayleigh equation (Mariotti et al., 1981): $\varepsilon=d_{\mathrm{s}}-d_{\mathrm{so}} / \ln f$, where $d_{\mathrm{s}}$ is the $\delta^{15} \mathrm{~N}$ natural abundance at different depths in the soil profile, $d_{\text {so }}$ is the $\delta^{15} \mathrm{~N}$ natural abundance of the reference depth (top $5 \mathrm{~cm}$ ) and $f$ is the fraction of total $\mathrm{N}$ remaining (i.e., the total $\mathrm{N}$ concentration at a given depth divided by the total $\mathrm{N}$ concentration in the top $5 \mathrm{~cm}$ ). The use of only surface $\delta^{15} \mathrm{~N}$ natural abundance values can be limited, given its inherently high spatial variability (i.e., due to vegetation species differences and surface topography). Therefore, we used not only the surface depth but also four depth increments to determine the overall natural abundance enrichment factor $(\varepsilon)$. The $\varepsilon$ value was used as an integrative indicator of soil $\mathrm{N}$ availability, as this correlates with internal soil-N cycling rates (Sotta et al., 2008; Baldos et al., 2015). Total organic C and $\mathrm{N}$ were measured from the ground soil samples by dry combustion using a $\mathrm{CN}$ analyzer (vario EL cube; Elementar Analysis Sys- tems GmbH, Hanau, Germany). ECEC was determined from the sieved soil samples by percolating with unbuffered $1 \mathrm{M}$ $\mathrm{NH}_{4} \mathrm{Cl}$ and measuring the exchangeable element concentrations ( $\mathrm{Ca}, \mathrm{Mg}, \mathrm{K}, \mathrm{Mn}, \mathrm{Na}, \mathrm{Fe}$ and $\mathrm{Al}$ ) in the percolates using an inductively coupled plasma-atomic emission spectrometer (ICP-AES; Spectroflame; Spectro Analytical Instruments, Kleve, Germany). Base saturation was calculated as the ratio of exchangeable base cations to the ECEC. Soil $\mathrm{pH}\left(\mathrm{H}_{2} \mathrm{O}\right)$ was analyzed from a 1:4 soil-to-water ratio. The particle size distribution of the mineral soil was determined using the pipette method with pyrophosphate as a dispersing agent (König and Fortmann, 1996).

\subsection{Soil fertility index}

The variation in soil types along our rainfall gradient (Table 1) was paralleled with variations in soil biochemical characteristics (Table 2; see Sect. 3.1). Thus, we developed a soil fertility index using principal component analysis (PCA), similar to the approach employed by Swaine (1996). For each site, the index was based on five soil physical and biochemical properties: (1) clay content, which reflects water- and nutrient-holding capacity, (2) $\varepsilon$, which signifies long-term soil $\mathrm{N}$ status, (3) ECEC and (4) soil $\mathrm{C}: \mathrm{N}$ ratio, which indicate the bioavailability of rock-derived nutrients and soil organic matter, and (5) exchangeable $\mathrm{Al}$, which implies soil chemical suitability. We used the depth-weighted average of these soil parameters (Table 2) measured at various depth intervals in the top $50 \mathrm{~cm}$ of depth (except for $\varepsilon$, which is calculated for the whole depth; see above). The first component factor of this PCA analysis explained $42 \%$ of the variation in these soil characteristics among sites (Fig. S2), and the factor scores were used as the quantitative index of soil fertility for each of the four replicate plots per site. This analysis showed that the soil fertility of the five lowland forests varied orthogonally with the precipitation gradient (Fig. S2).

\subsection{Statistical analyses}

We note that our statistical tests are based on the four replicate plots in each of the five 1 ha forest sites along these orthogonal gradients of precipitation and soil fertility, and that the sites themselves were not replicated along the gradients. Consequently, our interpretations and conclusions are limited only to these studied sites.

Soil trace gas fluxes (based on the average of the four chambers per replicate plot on each sampling day) and the accompanying soil explanatory variables (soil temperature, gravimetric moisture, $\mathrm{NH}_{4}^{+}$concentration and $\mathrm{NO}_{3}^{-}$concentration) were tested for normality using the Shapiro-Wilk test; variables with non-normal distributions were square root or log transformed. We then used linear mixed-effects models (LMEs) to assess the differences in these repeatedly measured variables along the orthogonal precipitation and soil fertility gradients with the site and/or the season as the fixed 
Table 2. Soil biochemical characteristics in the top $50 \mathrm{~cm}$ of lowland forest soils along orthogonal gradients of annual precipitation (shown in brackets below each site) and soil fertility in the Panama Canal watershed, central Panama.

\begin{tabular}{|c|c|c|c|c|c|}
\hline $\begin{array}{l}\text { Soil } \\
\text { characteristics }^{\mathrm{a}}\end{array}$ & $\begin{array}{r}\text { Metropolitan } \\
(1700 \mathrm{~mm})\end{array}$ & $\begin{array}{r}\text { P27 } \\
(2030 \mathrm{~mm})\end{array}$ & $\begin{array}{r}\mathrm{P} 8 \\
(2360 \mathrm{~mm})\end{array}$ & $\begin{array}{r}\text { P19 } \\
(2690 \mathrm{~mm})\end{array}$ & $\begin{array}{r}\text { P32 } \\
(3400 \mathrm{~mm})\end{array}$ \\
\hline $\begin{array}{l}\delta^{15} \mathrm{~N} \text { enrichment } \\
\text { factor, } \varepsilon^{\mathrm{b}}\end{array}$ & $-1.95 \pm 0.52^{\mathrm{b}}$ & $-0.37 \pm 1.69^{b}$ & $-2.76 \pm 0.54^{\mathrm{ab}}$ & $-4.70 \pm 0.44^{\mathrm{a}}$ & $-2.65 \pm 0.30^{\mathrm{ab}}$ \\
\hline $\begin{array}{l}\delta^{15} \mathrm{~N} \text { natural } \\
\text { abundance }(\% \circ)\end{array}$ & $5.9 \pm 0.8^{\mathrm{c}}$ & $6.3 \pm 0.4^{\mathrm{bc}}$ & $12.0 \pm 1.0^{\mathrm{a}}$ & $9.2 \pm 0.9^{\mathrm{a}}$ & $7.0 \pm 0.3^{\mathrm{b}}$ \\
\hline $\begin{array}{l}\text { Organic C } \\
\left(\mathrm{mg} \mathrm{Cg}^{-1}\right)\end{array}$ & $12.8 \pm 1.7^{\mathrm{ab}}$ & $10.8 \pm 3.3^{\mathrm{b}}$ & $15.1 \pm 0.2^{\mathrm{ab}}$ & $15.0 \pm 1.3^{\mathrm{ab}}$ & $19.6 \pm 2.1^{\mathrm{a}}$ \\
\hline $\begin{array}{l}\text { Total N } \\
\left(\mathrm{mg} \mathrm{C}^{-1}\right)\end{array}$ & $1.08 \pm 0.15^{\mathrm{b}}$ & $1.05 \pm 0.25^{\mathrm{b}}$ & $1.49 \pm 0.02^{\mathrm{ab}}$ & $1.44 \pm 0.11^{\mathrm{ab}}$ & $1.85 \pm 0.17^{\mathrm{a}}$ \\
\hline $\mathrm{C}: \mathrm{N}$ ratio & $10.9 \pm 4.1^{\mathrm{a}}$ & $9.07 \pm 1.8^{\mathrm{a}}$ & $9.76 \pm 1.0^{\mathrm{a}}$ & $9.88 \pm 1.0^{\mathrm{a}}$ & $10.1 \pm 1.2^{\mathrm{a}}$ \\
\hline $\begin{array}{l}\mathrm{pH} \\
\left(1: 4 \mathrm{H}_{2} \mathrm{O}\right)\end{array}$ & $6.20 \pm 0.46^{\mathrm{a}}$ & $5.82 \pm 0.72^{\mathrm{a}}$ & $5.05 \pm 0.17^{b}$ & $4.88 \pm 0.30^{\mathrm{b}}$ & $5.14 \pm 0.22^{\mathrm{b}}$ \\
\hline $\begin{array}{l}\mathrm{ECEC}^{\mathrm{c}} \\
\left(\mathrm{mmol}_{\mathrm{C}} \mathrm{kg}^{-1}\right)\end{array}$ & $199 \pm 72^{\mathrm{ab}}$ & $267 \pm 11^{\mathrm{a}}$ & $56 \pm 2^{\mathrm{c}}$ & $51 \pm 6^{\mathrm{c}}$ & $118 \pm 12^{\mathrm{bc}}$ \\
\hline $\begin{array}{l}\text { Exch. bases } \\
\left(\mathrm{mmol}_{C} \mathrm{~kg}^{-1}\right)\end{array}$ & $198 \pm 72^{\mathrm{a}}$ & $264 \pm 10^{\mathrm{a}}$ & $37 \pm 6^{\mathrm{c}}$ & $21 \pm 8^{\mathrm{c}}$ & $90 \pm 11^{b}$ \\
\hline $\begin{array}{l}\text { Exchangeable Al } \\
\left(\mathrm{mmol}_{\mathrm{C}} \mathrm{kg}^{-1}\right)\end{array}$ & $0.22 \pm 0.13^{b}$ & $1.96 \pm 0.51^{b}$ & $12.2 \pm 4.7^{\mathrm{ab}}$ & $22.6 \pm 7.3^{\mathrm{a}}$ & $22.2 \pm 3.2^{\mathrm{a}}$ \\
\hline
\end{tabular}

${ }^{a}$ Means ( \pm SE, $n=4$ ) followed by different letters indicate significant differences between sites (one-way ANOVA with Tukey's HSD at $P \leq 0.05$ ). Values for each replicate plot are the weighted average of the sampling depth intervals at $0-5,5-10,10-25$ and $25-50 \mathrm{~cm}$.

b Calculated using the Rayleigh equation (Mariotti et al., 1981): $\varepsilon=d_{\mathrm{S}}-d_{\mathrm{So}} / \ln f ; d_{\mathrm{S}}-\delta^{15} \mathrm{~N}$ natural abundance signatures at various depths in the soil profile, $d_{\text {so }}-\delta^{15} \mathrm{~N}$ natural abundance of the reference depth (top $5 \mathrm{~cm}$ ); $f$ is the remaining fraction of total $\mathrm{N}$ (i.e., total $\mathrm{N}$ concentration at a given depth divided by the total $\mathrm{N}$ concentration in the top $5 \mathrm{~cm}$ ). ${ }^{\mathrm{c}}$ ECEC: effective cation exchange capacity; Exch. bases: sum of exchangeable $\mathrm{Ca}, \mathrm{Mg}, \mathrm{K}, \mathrm{Na}$.

effect(s) and the sampling days and replicate plots as random effects. If the Akaike information criterion (AIC) showed an improvement in the LME models, we included a first-order temporal autoregressive function to account for the decreasing correlation of the measurements with increasing time (Zuur et al., 2009) and/or a variance function (varIdent) to account for heteroscedasticity in the fixed-factor variances (Crawley, 2012). To assess the relationships between soil trace gas fluxes and soil explanatory variables, we used the mean values of the four replicate plots on each sampling date, and conducted Pearson correlation tests over the entire sampling period across the five sites and for each site. Lastly, we analyzed the hierarchy of importance for the soilcontrolling factors of soil trace gas fluxes by selecting the minimal adequate LME model. For this, we used a stepwise model simplification in which each controlling factor was tested against a null model. The soil factor that showed the lowest AIC value was ranked as the most important; the soil factors with the next lowest AIC values were added stepwise into the model if this significantly improve the model fit. This analysis was conducted on the mean values of the four replicate plots on each sampling date over the sampling period across the five sites and for each site.

For the soil biochemical characteristics measured only once (Table 2), differences in depth-weighted values (for the top $50 \mathrm{~cm}$ ) among sites were evaluated using a one-way anal- ysis of variance followed by a Tukey's HSD test. Their relationships with soil trace gas fluxes across the five sites (using annual values and average seasonal values) were tested using Spearman rank correlations. In all statistical tests, differences among sites or between seasons, correlation coefficients and minimal adequate LME models were considered significant at $P \leq 0.05$.

Data analyses were conducted using the $\mathrm{R}$ open-source software (R Core Team, 2013).

\section{Results}

\subsection{Soil biochemical characteristics}

The soil $\delta^{15} \mathrm{~N}$ natural abundance signatures and $\varepsilon$, which are proxies for the long-term soil $\mathrm{N}$ status (i.e., the higher the values, the higher the soil $\mathrm{N}$ availability), were lower at the lowrainfall sites (Met and P27) than at one of the mid-rainfall sites (P19; $P \leq 0.05$; Table 2). Soil organic $\mathrm{C}$ was lower at one of the lower-rainfall sites (P27) than at the high-rainfall site (P32), whereas the differences in total soil $\mathrm{N}$ among sites paralleled the increase in annual precipitation $(P \leq 0.05$; Table 2). Soil pH, ECEC and exchangeable bases generally showed the opposite trend to that of total soil N, with higher values at the low-rainfall sites (with less-weathered soils) than at the mid- and high-rainfall sites (with highly weath- 

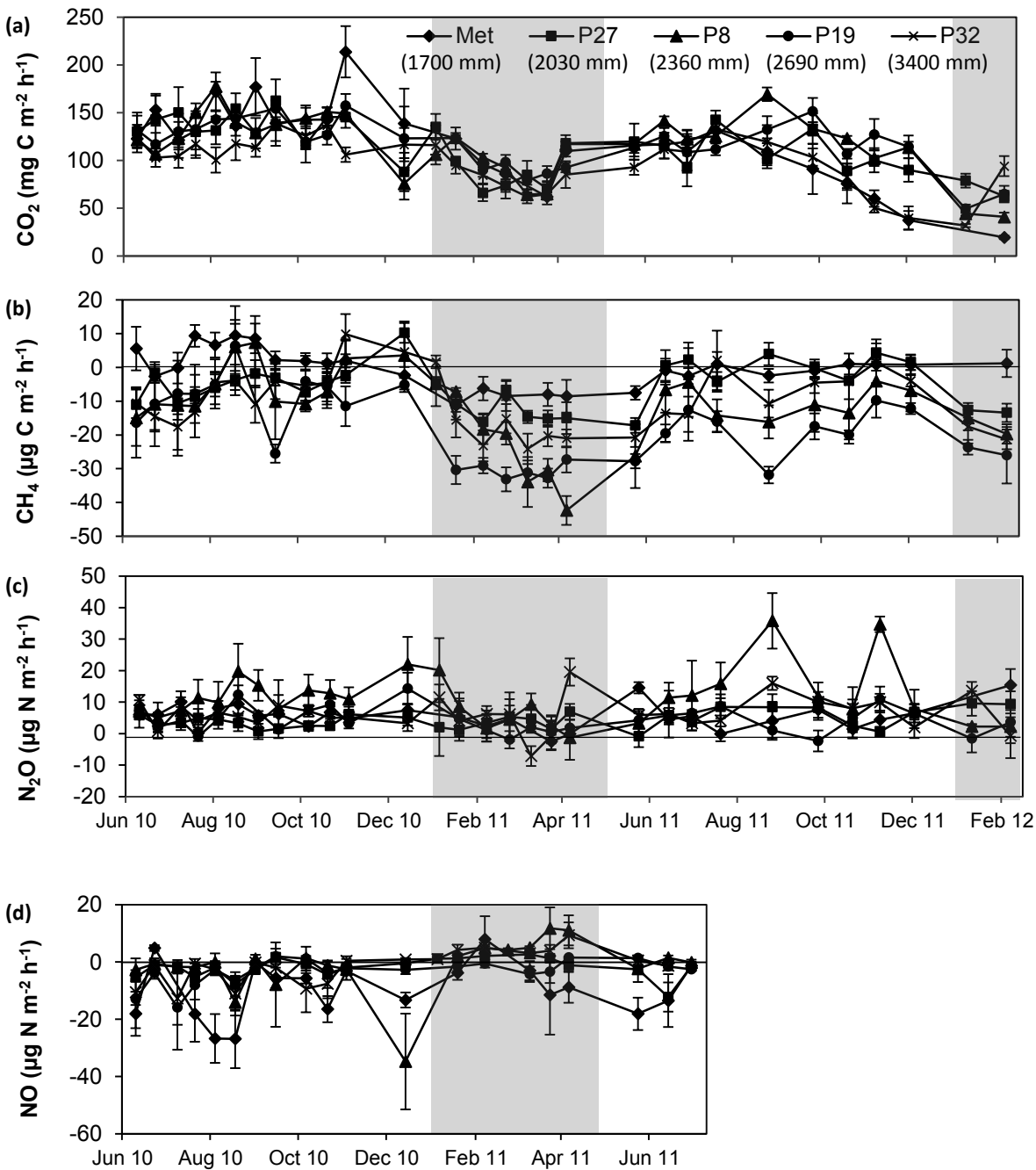

Figure 2. Mean ( $\pm \mathrm{SE}, n=4)$ soil (a) $\mathrm{CO}_{2}$, (b) $\mathrm{CH}_{4}$, (c) $\mathrm{N}_{2} \mathrm{O}$ and (d) $\mathrm{NO}$ fluxes from lowland forests along orthogonal gradients of annual precipitation and soil fertility in the Panama Canal watershed, central Panama. The gray shading indicates the dry season (January through April).

ered soils; all $P \leq 0.05$; Tables 1 and 2). Soil exchangeable $\mathrm{Al}$ showed the converse pattern to that of exchangeable bases $(P \leq 0.02$; Table 2).

Of the four soil-controlling factors that were monitored over time (temperature, moisture, extractable $\mathrm{NH}_{4}^{+}$and extractable $\mathrm{NO}_{3}^{-}$; Fig. 1a-d), only moisture and extractable $\mathrm{NO}_{3}^{-}$differed strongly between seasons $(P<0.01$; Fig. $1 \mathrm{~b}-$ c; Table 3). Soil moisture contents were higher in the wet season than the dry season at all sites, while extractable soil $\mathrm{NO}_{3}^{-}$concentrations were lower in the wet season that the dry season at all sites but P19. Temperature and extractable $\mathrm{NH}_{4}^{+}$exhibited between-season differences at only one site each (temperature $\mathrm{P} 8$; extractable $\mathrm{NH}_{4}^{+} \mathrm{P} 27$; Table 3). Within each season, all four soil-controlling factors differed along the precipitation gradient (all $P<0.01$ except $P=0.04$ for extractable $\mathrm{NH}_{4}^{+}$in the wet season; Table 3). Soil temperatures in both seasons were lower at P32 $(3400 \mathrm{~mm})$ than at all other sites (not significant at P27 in the dry season), and also lower at P27 $(2030 \mathrm{~mm})$ than Met $(1700 \mathrm{~mm})$. Soil moisture contents, in contrast, were higher in both seasons at P32 than at the other four sites. Extractable soil $\mathrm{NO}_{3}^{-}$ concentrations in both seasons were higher at Met and P8 $(2360 \mathrm{~mm})$ than at P27, P19 $(2690 \mathrm{~mm})$ and P32; in the wet season, they were also higher at Met than P8. Extractable soil $\mathrm{NH}_{4}^{+}$concentrations were higher at P32 than Met in both seasons. Across sites over the 21-month measurement period, soil moisture was inversely correlated with temperature $(r=-0.28, P<0.01, n=145)$ and extractable soil $\mathrm{NO}_{3}^{-}$ $(r=-0.51, P<0.01, n=145)$ and directly correlated with extractable soil $\mathrm{NH}_{4}^{+}(r=0.46, P<0.01, n=145)$. 
Table 3. Soil factors (measured in the top $5 \mathrm{~cm}$ of soil) and trace gas fluxes from lowland forest soils along orthogonal gradients of annual precipitation (mm per year; shown in brackets for each site) and soil fertility in the Panama Canal watershed, central Panama.

\begin{tabular}{|c|c|c|c|c|c|c|c|c|}
\hline Site/season ${ }^{\mathrm{a}}$ & $\begin{array}{r}\text { Soil } \\
\text { temperature }\left({ }^{\circ} \mathrm{C}\right)\end{array}$ & $\begin{array}{r}\text { Soil moisture } \\
\left(\mathrm{g} \mathrm{g}^{-1}\right)\end{array}$ & $\begin{array}{r}\text { Soil NH } \mathrm{NH}_{4}^{+} \\
\left(\mathrm{mg} \mathrm{N} \mathrm{kg}^{-1}\right)\end{array}$ & $\begin{array}{r}\text { Soil NO} \mathrm{NO}_{3}^{-} \\
\left(\mathrm{mg} \mathrm{N} \mathrm{kg}^{-1}\right)\end{array}$ & $\begin{array}{r}\mathrm{CO}_{2} \text { flux } \\
\left(\mathrm{mg} \mathrm{C} \mathrm{m}^{-2} \mathrm{~h}^{-1}\right)\end{array}$ & $\begin{array}{r}\mathrm{CH}_{4} \text { flux } \\
\left(\mu \mathrm{g} \mathrm{C} \mathrm{m}{ }^{-2} \mathrm{~h}^{-1}\right)\end{array}$ & $\begin{array}{r}\mathrm{N}_{2} \mathrm{O} \text { flux } \\
\left(\mu \mathrm{g} \mathrm{N} \mathrm{m}^{-2} \mathrm{~h}^{-1}\right)\end{array}$ & $\begin{array}{r}\text { NO flux } \\
\left(\mu \mathrm{g} \mathrm{N} \mathrm{m}{ }^{-2} \mathrm{~h}^{-1}\right)\end{array}$ \\
\hline \multicolumn{9}{|l|}{ Wet season } \\
\hline Metropolitan (1700) & $25.8(0.4)^{\mathrm{a}}$ & $0.64(0.04)^{\mathrm{Ac}}$ & $5.94(1.52)^{\mathrm{b}}$ & $1.95(0.71)^{\mathrm{Ba}}$ & $126(26)^{\mathrm{A}}$ & $1.47(3.66)^{\mathrm{Aa}}$ & $5.78(2.69)^{\mathrm{b}}$ & $-11.6(7.08)^{\mathrm{Bb}}$ \\
\hline P27 (2030) & $25.2(0.4)^{b}$ & $0.72(0.06)^{\mathrm{Ab}}$ & $6.39(1.35)^{\mathrm{Aab}}$ & $0.51(0.17)^{\mathrm{Bc}}$ & $124(18)^{\mathrm{A}}$ & $-3.01(4.20)^{\mathrm{Aa}}$ & $4.15(2.56)^{\mathrm{b}}$ & $-3.24(2.68)^{\mathrm{Ba}}$ \\
\hline P8 (2360) & $25.6(0.4)^{\mathrm{Aab}}$ & $0.60(0.03)^{\mathrm{Ac}}$ & $5.68(0.94)^{\mathrm{ab}}$ & $1.32(0.54)^{\mathrm{Bb}}$ & $131(19)^{\mathrm{A}}$ & $-7.87(6.95)^{\mathrm{A} b c}$ & $13.5(7.0)^{\mathrm{A} a}$ & $-3.95(6.60)^{\mathrm{Ba}}$ \\
\hline P19 (2690) & $25.5(0.5)^{\mathrm{ab}}$ & $0.72(0.06)^{\mathrm{Ab}}$ & $7.29(1.39)^{\mathrm{ab}}$ & $0.46(0.39)^{\mathrm{c}}$ & $129(15)^{\mathrm{A}}$ & $-13.0(6.92)^{\mathrm{Ac}}$ & $5.58(3.13)^{\mathrm{Ab}}$ & $-3.98(4.95)^{\mathrm{a}}$ \\
\hline P32 (3400) & $24.6(0.4)^{\mathrm{c}}$ & $0.90(0.08)^{\mathrm{Aa}}$ & $8.21(1.87)^{\mathrm{Aa}}$ & $0.49(0.27)^{\mathrm{Bc}}$ & $107(17)^{\mathrm{A}}$ & $-6.79(6.09)^{\text {Aab }}$ & $6.41(3.09)^{\mathrm{b}}$ & $-4.01(4.34)^{\mathrm{Ba}}$ \\
\hline \multicolumn{9}{|l|}{ Dry season } \\
\hline Metropolitan (1700) & $25.3(0.3)^{\mathrm{a}}$ & $0.45(0.06)^{\mathrm{Bb}}$ & $5.32(1.26)^{\mathrm{bc}}$ & $3.42(1.55)^{\mathrm{Aa}}$ & $82.7(19)^{\mathrm{B}}$ & $-6.88(4.14)^{\mathrm{Ba}}$ & $4.18(4.62)$ & $-4.05(7.21)^{\mathrm{Aab}}$ \\
\hline P27 (2030) & $24.7(0.2)^{\mathrm{bc}}$ & $0.53(0.08)^{\mathrm{Bab}}$ & $4.46(0.89)^{\mathrm{Bc}}$ & $0.79(0.18)^{\mathrm{Ab}}$ & $87.7(14)^{\mathrm{B}}$ & $-12.1(3.1)^{\mathrm{Bab}}$ & $4.87(4.70)$ & $1.09(1.23)^{\mathrm{Aab}}$ \\
\hline P8 (2360) & $24.9(0.3)^{\mathrm{Bab}}$ & $0.48(0.06)^{\mathrm{Bb}}$ & $6.04(1.15)^{\mathrm{abc}}$ & $3.68(1.16)^{\mathrm{Aa}}$ & $85.7(17)^{\mathrm{B}}$ & $-21.3(8.37)^{\mathrm{Bbc}}$ & $5.64(5.75)^{\mathrm{B}}$ & $6.50(3.76)^{\mathrm{Aa}}$ \\
\hline P19 (2690) & $25.0(0.3)^{\mathrm{ab}}$ & $0.49(0.04)^{\mathrm{Bb}}$ & $7.47(1.22)^{\mathrm{ab}}$ & $0.64(0.26)^{\mathrm{b}}$ & $85.5(12)^{\mathrm{B}}$ & $-29.2(4.08)^{\mathrm{Bc}}$ & $1.30(3.09)^{\mathrm{B}}$ & $-2.41(2.35)^{b}$ \\
\hline P32 (3400) & $24.4(0.3)^{\mathrm{c}}$ & $0.64(0.09)^{\mathrm{Ba}}$ & $7.86(1.37)^{\mathrm{a}}$ & $1.17(0.61)^{\mathrm{Ab}}$ & $78.5(15)^{\mathrm{B}}$ & $-17.4(5.09)^{\mathrm{Bab}}$ & $5.89(5.51)$ & $4.34(2.23)^{\mathrm{Aa}}$ \\
\hline
\end{tabular}

\section{2 $\mathrm{CO}_{2}$ fluxes}

Although soil $\mathrm{CO}_{2}$ emissions did not differ among the five sites over the 21-month measurement period $(P=0.40$; Fig. 2a; Table 3), emissions exhibited a parabolic relationship with soil moisture across sites (Fig. 3) and were higher in the wet season than the dry season at each site $(P \leq 0.05$; Table 3). Over the 21-month sampling period, average daily soil $\mathrm{CO}_{2}$ emissions from the five sites were correlated with soil moisture ( $r=0.35, P<0.01, n=145$; Fig. 3 ), soil temperature $(r=0.46, P<0.01, n=145)$, extractable soil $\mathrm{NH}_{4}^{+}$ $(r=0.32, P<0.01, n=145)$ and extractable soil $\mathrm{NO}_{3}^{-}(r=$ $-0.21, P=0.01, n=145)$; the dominant driver in the wet season was extractable $\mathrm{NH}_{4}^{+}$followed by temperature, while the dominant driver in the dry season was moisture followed by temperature (Table $\mathrm{S} 1$ in the Supplement). Within individual sites, daily soil $\mathrm{CO}_{2}$ emissions exhibited negative correlations with extractable soil $\mathrm{NO}_{3}^{-}$at Met $(r=-0.48$, $P=0.01, n=27), \mathrm{P} 8(r=-0.39, P=0.03, n=30)$ and P32 ( $r=-0.54, P<0.01, n=30)$. Moisture was a dominant driver of $\mathrm{CO}_{2}$ emissions from soils at all sites, with temperature (P27, P8 and P32) and mineral N (Met, P19 and P32) both playing important roles as well (Table S1).

Similar to the relationship observed for average daily fluxes (Fig. 3), the annual soil $\mathrm{CO}_{2}$ emissions (Table 4) also exhibited a parabolic pattern across the five sites of the precipitation gradient: high at the mid-rainfall sites (P8 and P19) and low at both ends of the precipitation gradient (Met and $\mathrm{P} 32)$. There were no significant correlations between soil $\mathrm{CO}_{2}$ emissions (neither for annual $\mathrm{CO}_{2}$ fluxes nor for wet and dry season averages) and the soil biochemical characteristics (Tables 5, S2).

\section{$3.3 \quad \mathrm{CH}_{4}$ fluxes}

On average, despite occasional emissions in the wet season (Fig. 2b), the soils in the five sites acted as $\mathrm{CH}_{4}$ sinks (Ta-

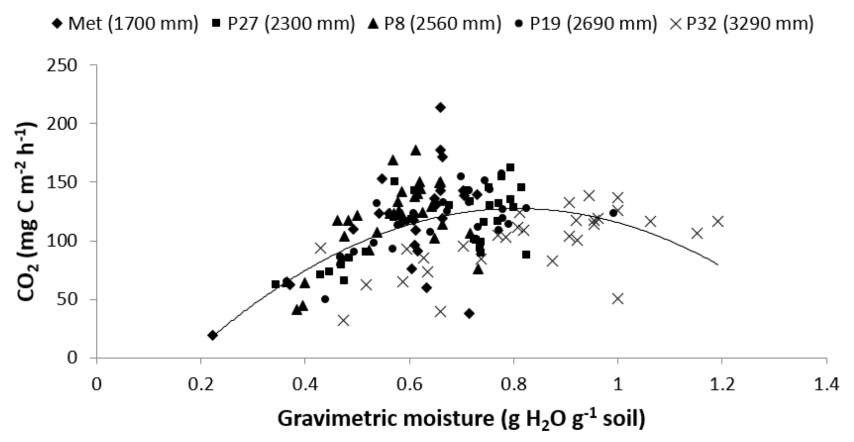

Figure 3. Soil $\mathrm{CO}_{2}$ fluxes and moisture contents (top $5 \mathrm{~cm}$ ) in five lowland forests along orthogonal gradients of annual precipitation (shown in brackets) and soil fertility in the Panama Canal watershed, central Panama. Each data point is the average of four replicate plots on 1 sampling day from one of the five sites measured from June 2010 to February 2012; the quadratic regression across sites (shown) is $y=-321.1 x^{2}+517.8 x-81.2\left(R^{2}=0.30\right.$, $n=145, P<0.01)$.

bles 3 and 4). Comparing between seasons, soil $\mathrm{CH}_{4}$ uptake was higher in the dry season than the wet season at all sites ( $P \leq 0.05$; Table 3 ). Moisture was a dominant driver of $\mathrm{CH}_{4}$ flux in both seasons but was stronger in the wet season (Table S1). Differences among sites were the same in both seasons; soil $\mathrm{CH}_{4}$ uptake at P19 (2690 mm) was higher than at Met (1700 mm), P27 (2030 mm) and P32 (3400 mm), and higher at P8 $(2360 \mathrm{~mm})$ than at Met $(P \leq 0.05$; Table 3). Over the 21-month sampling period, average daily soil $\mathrm{CH}_{4}$ fluxes from the five sites were positively correlated (i.e., soil $\mathrm{CH}_{4}$ uptake decreased) with soil moisture $(r=0.44$, $P<0.01, n=145$; Fig. 4a); moisture was also the dominant within-site driving factor at all sites except Met (Table S1). Across sites, mineral $\mathrm{N}$ was a significant explanatory factor in both seasons; within sites, this was only reflected in the model at P32 (Table S1), but average daily soil $\mathrm{CH}_{4}$ fluxes at 
Table 4. Annual* trace gas fluxes (mean $(\mathrm{SE}), n=4)$ from lowland tropical forest soils along orthogonal gradients of annual precipitation and soil fertility in the Panama Canal watershed, central Panama.

\begin{tabular}{lrrrr}
\hline $\begin{array}{l}\text { Site (annual } \\
\text { precipitation) }\end{array}$ & $\begin{array}{r}\mathrm{CO}_{2} \\
\left(\mathrm{Mg} \mathrm{Cha}^{-1} \mathrm{yr}^{-1}\right)\end{array}$ & $\begin{array}{r}\mathrm{CH}_{4} \\
\left(\mathrm{~kg} \mathrm{Cha}^{-1} \mathrm{yr}^{-1}\right)\end{array}$ & $\begin{array}{r}\mathrm{N}_{2} \mathrm{O} \\
\left(\mathrm{kg} \mathrm{Nha}^{-1} \mathrm{yr}^{-1}\right)\end{array}$ & $\begin{array}{r}\mathrm{NO} \\
\left(\mathrm{kg} \mathrm{N} \mathrm{ha}^{-1} \mathrm{yr}^{-1}\right)\end{array}$ \\
\hline Met $(1700 \mathrm{~mm})$ & $8.48(0.70)$ & $-0.34(0.17)$ & $0.41(0.06)$ & $-0.82(0.16)$ \\
P27 $(2030 \mathrm{~mm})$ & $9.16(0.62)$ & $-0.51(0.04)$ & $0.43(0.06)$ & $-0.12(0.04)$ \\
P8 $(2360 \mathrm{~mm})$ & $10.14(0.76)$ & $-1.45(0.15)$ & $1.07(0.15)$ & $-0.17(0.17)$ \\
P19 $(2690 \mathrm{~mm})$ & $9.89(0.49)$ & $-1.98(0.07)$ & $0.35(0.05)$ & $-0.21(0.10)$ \\
P32 $(3400 \mathrm{~mm})$ & $7.89(0.84)$ & $-0.94(0.19)$ & $0.66(0.18)$ & $-0.03(0.09)$ \\
\hline
\end{tabular}

* Calculated using the trapezoidal rule between fluxes and time interval covering the measurement periods of January to December 2011 for $\mathrm{CO}_{2}, \mathrm{CH}_{4}$ and $\mathrm{N}_{2} \mathrm{O}$, and June 2010 to May 2011 for NO. Annual fluxes were not tested statistically for differences among sites since these are trapezoidal extrapolations.

Table 5. Spearman correlations of soil biochemical characteristics ${ }^{1}$ and annual (measured in 2011) soil trace gas fluxes from five lowland tropical forests along orthogonal precipitation and fertility gradients in the Panama Canal watershed, central Panama.

\begin{tabular}{|c|c|c|c|c|c|c|c|c|c|c|}
\hline & ECEC & BS & $\mathrm{Na}$ & $\mathrm{Al}$ & $\mathrm{pH}$ & Clay & $\mathrm{CO}_{2}$ & $\mathrm{CH}_{4}$ & $\mathrm{~N}_{2} \mathrm{O}$ & NO \\
\hline${ }^{15} \mathrm{~N}$ sig. & $-0.87^{* *}$ & $-0.67^{* *}$ & -0.30 & 0.42 & $-0.61^{* *}$ & -0.15 & 0.41 & $-0.70^{* *}$ & 0.30 & 0.16 \\
\hline ECEC & & $0.80^{* *}$ & 0.34 & -0.50 & $0.76^{* *}$ & -0.12 & -0.33 & $0.77^{* *}$ & -0.09 & -0.17 \\
\hline BS & & & -0.13 & $-0.87^{* *}$ & $0.96^{* *}$ & -0.12 & -0.40 & $0.78^{* *}$ & -0.12 & -0.54 \\
\hline $\mathrm{Na}$ & & & & 0.45 & -0.18 & -0.15 & 0.04 & 0.01 & -0.01 & $0.60^{* *}$ \\
\hline $\mathrm{Al}$ & & & & & $-0.87^{* *}$ & 0.04 & 0.24 & $-0.71^{* *}$ & 0.17 & $0.58^{* *}$ \\
\hline $\mathrm{pH}$ & & & & & & -0.04 & -0.34 & $0.76^{* *}$ & -0.12 & -0.54 \\
\hline Clay & & & & & & & -0.13 & -0.17 & $-0.67^{* *}$ & -0.34 \\
\hline $\mathrm{CO}_{2}$ & & & & & & & & -0.24 & 0.26 & 0.10 \\
\hline $\mathrm{CH}_{4}$ & & & & & & & & & -0.07 & -0.31 \\
\hline $\mathrm{N}_{2} \mathrm{O}$ & & & & & & & & & & 0.19 \\
\hline
\end{tabular}

${ }^{* *} P<0.01, n=20$ (four replicate plots in each of the five forest sites). ${ }^{1}$ Soil parameter abbreviations: ${ }^{15} \mathrm{~N}$ natural abundance signature $\left({ }^{15} \mathrm{~N}\right.$ sig.), effective cation exchange capacity (ECEC) and base saturation (BS).

P8 $(r=-0.63, P<0.01, n=30), \mathrm{P} 19(r=-0.48, P<0.01$, $n=28)$ and $\mathrm{P} 32(r=-0.48, P<0.01, n=30)$ also exhibited negative correlations with extractable soil $\mathrm{NO}_{3}^{-}$(i.e., soil $\mathrm{CH}_{4}$ uptake increased as extractable soil $\mathrm{NO}_{3}^{-}$increased).

The annual soil $\mathrm{CH}_{4}$ fluxes (Table 4 ) were positively correlated (Spearman $\rho=0.84, P<0.01, n=20$; Fig. 4b) with the soil fertility index (Fig. S2) and negatively correlated with annual precipitation ( $\rho=-0.63, P<0.01, n=20$; Fig. 4c). Of the soil biochemical properties measured once, annual soil $\mathrm{CH}_{4}$ fluxes were negatively correlated with soil ${ }^{15} \mathrm{~N}$ natural abundance and exchangeable $\mathrm{Al}$, and positively correlated with ECEC, base saturation and $\mathrm{pH}$ (Table 5). Average seasonal soil $\mathrm{CH}_{4}$ fluxes exhibited similar correlations (Table S2); it is notable that when correlation analysis was separated by season, correlations with soil ${ }^{15} \mathrm{~N}$ natural abundance were stronger in the dry season than the wet season.

\section{$3.4 \quad \mathrm{~N}_{2} \mathrm{O}$ fluxes}

Soil $\mathrm{N}_{2} \mathrm{O}$ fluxes differed among sites only in the wet season and not in the dry season (Table 3; Fig. 2c); soil $\mathrm{N}_{2} \mathrm{O}$ emissions in the wet season were higher at P8 $(2360 \mathrm{~mm})$ than all other sites $(P<0.01)$. Notably, the model fit also in- dicated no significant soil factors for the dry season, but it did identify $\mathrm{NO}_{3}^{-}$as a driving factor across sites in the wet season (Table S1). Within individual sites, moisture was a controlling factor for $\mathrm{N}_{2} \mathrm{O}$ emissions at P8, P19 and P32, with $\mathrm{NO}_{3}^{-}$availability also important at P19 (Table S1). Comparing between sites, soil $\mathrm{N}_{2} \mathrm{O}$ emissions were higher in the wet season than the dry season at P8 and P19 $(2690 \mathrm{~mm}$; $P<0.01$; Table 3). These two sites were also the only two to exhibit correlations with soil-controlling factors; soil $\mathrm{N}_{2} \mathrm{O}$ emissions increased with increases in soil moisture at P8 $(r=0.69, P<0.01, n=30)$ and P19 ( $r=0.60, P<0.01$, $n=28)$ and decreased with increases in soil $\mathrm{NO}_{3}^{-}$concentration at $\mathrm{P} 8(r=-0.57, P<0.01, n=30)$ and $\mathrm{P} 19(r=-0.38$, $P=0.05, n=28)$. Annual soil $\mathrm{N}_{2} \mathrm{O}$ emissions (Table 4) were negatively correlated with clay content (Table 5). Seasonal average soil $\mathrm{N}_{2} \mathrm{O}$ emissions were positively correlated with soil ${ }^{15} \mathrm{~N}$ natural abundance in the wet season but not in the dry season (Table S2).

\subsection{NO fluxes}

In all five sites, the net uptake of $\mathrm{NO}$ or negative $\mathrm{NO}$ flux was measured more often than net NO emissions from 

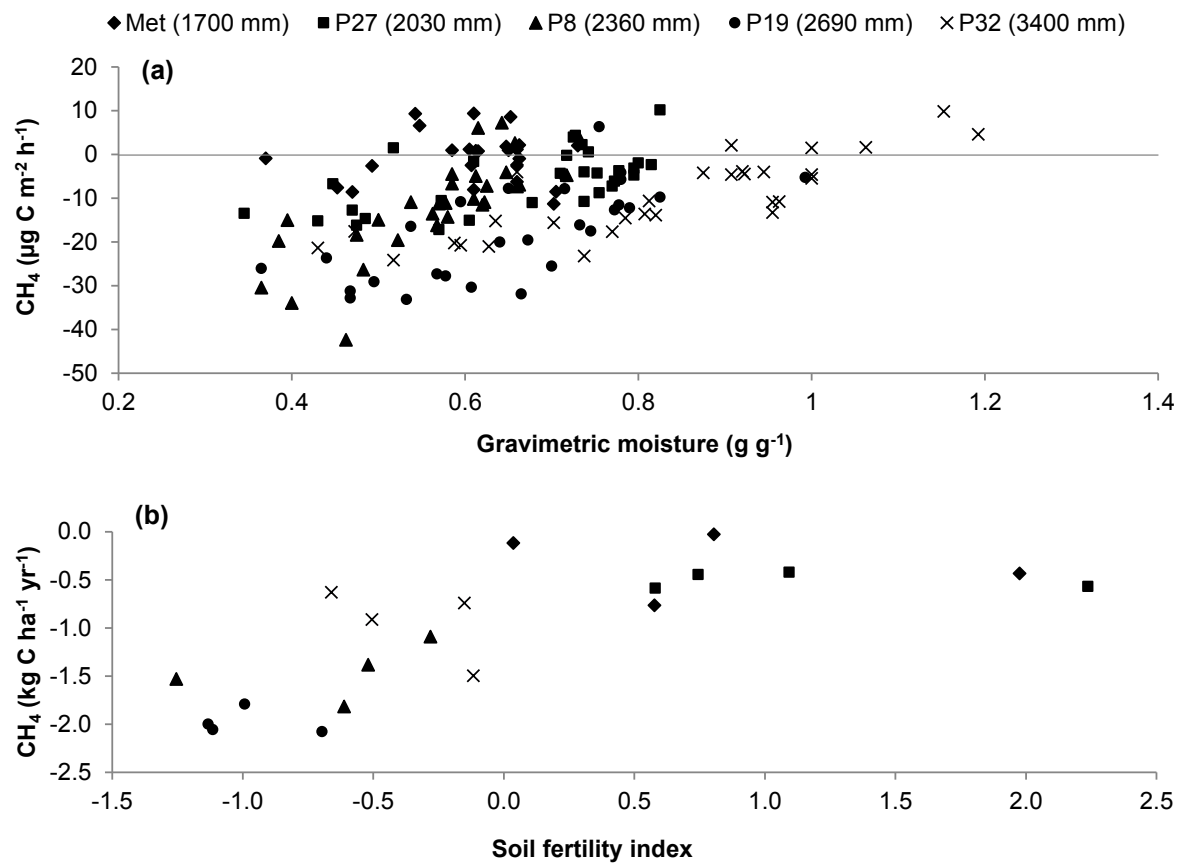

(c)

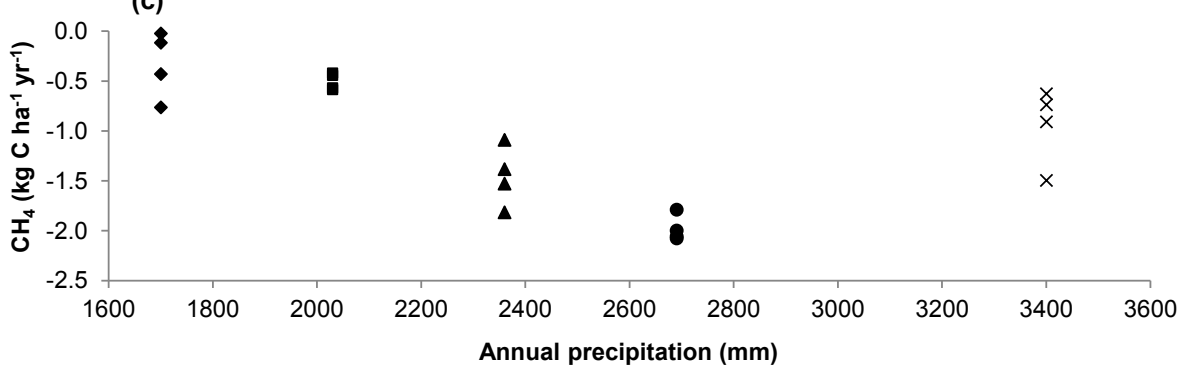

Figure 4. Average daily soil $\mathrm{CH}_{4}$ fluxes plotted against (a) soil moisture (top $5 \mathrm{~cm}$ ), and annual soil $\mathrm{CH}_{4}$ fluxes plotted against (b) soil fertility index and (c) annual precipitation. For (a), each data point is the average of four replicate plots on each sampling day for each of the five sites measured from June 2010 to February 2012. The five lowland forests are located along orthogonal gradients of annual precipitation and soil fertility in the Panama Canal watershed, central Panama.

the soil (Fig. 2d); net NO uptake was consistently higher $(P \leq 0.05)$ in the wet than the dry season, except at P19 $(2690 \mathrm{~mm})$ where there was no difference between seasons (Table 3). Wet season soil NO uptake at Met $(1700 \mathrm{~mm})$ was larger than all other sites $(P<0.01$; Table 3$)$, while in the dry season soil NO uptake at P19 was larger than at P8 $(2360 \mathrm{~mm})$ and P32 (3400 mm; $P<0.01$; Table 3). Over the 13-month measurement period, there were no driving factors that were significant across sites in the model fit (Table S1) but soil NO fluxes were negatively correlated (i.e., net NO uptake increased) with ambient NO concentration ( $r=-0.34, P<0.01, n=103$; Fig. 5). Within individual sites, the dominant drivers (Table S1) were moisture (P27 and P8) and temperature (P27), with soil NO fluxes at $\mathrm{P} 8$ also exhibiting a negative correlation with soil moisture $(r=-0.67, P<0.01 ; n=21)$ and a positive correlation (i.e., net $\mathrm{NO}$ uptake decreased) with extractable soil $\mathrm{NO}_{3}^{-}$ $(r=0.65, P<0.01 ; n=21)$. There were no correlations with average seasonal soil NO fluxes in the wet season, but in the dry season average seasonal soil NO fluxes were negatively correlated with clay content across sites (Table S2).

\section{Discussion}

\section{1 $\mathrm{CO}_{2}$ fluxes}

Soil $\mathrm{CO}_{2}$ emissions from CSA tropical lowland forests, including Brazil (Davidson et al., 2000; Chambers et al., 2004; Silver et al., 2005; Sotta et al., 2006), Puerto Rico (Raich and Schlesinger, 1992), Panama (Kursar, 1989; Koehler et al., 2009a; Nottingham et al., 2010) and Costa Rica (Schwendenmann and Veldkamp, 2006), range from $10.8 \mathrm{Mg}$ C (Silver et al., 2005) to $39.7 \mathrm{Mg} \mathrm{Cha}^{-1} \mathrm{yr}^{-1}$ (Sotta et al., 2006). Our annual soil $\mathrm{CO}_{2}$ emissions (Table 4) were on the lower end of this range. When compared with other studies in low- 


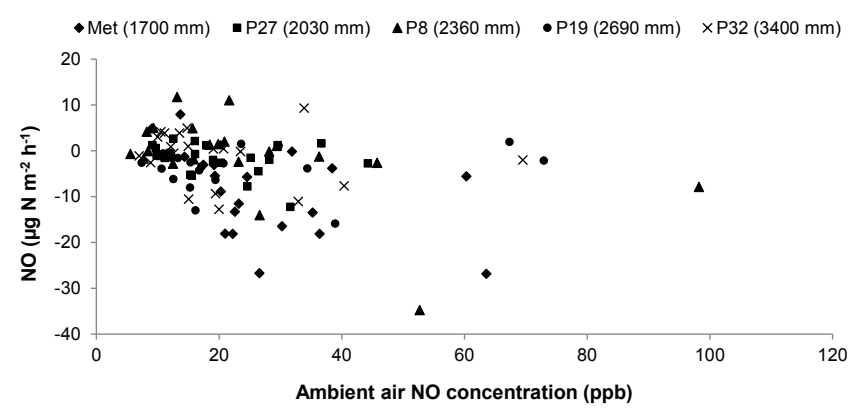

Figure 5. Soil NO fluxes plotted against ambient air NO concentrations; each data point is the average of four replicate plots on each sampling day in each of the five sites measured from June 2010 to June 2011. The five lowland forests are located along orthogonal gradients of annual precipitation and soil fertility in the Panama Canal watershed, central Panama.

land forests of Panama, our values were also at the lower end of those reported for Barro Colorado Island (BCI; estimated at $14.5 \mathrm{Mg} \mathrm{Cha}^{-1} \mathrm{yr}^{-1}$ in 1986; Kursar, 1989) and Gigante (ranging from $13.59 \pm 1.34$ to $17.12 \pm 1.59 \mathrm{Mg} \mathrm{Cha}^{-1} \mathrm{yr}^{-1}$ between 2006 and 2008; Koehler et al., 2009a), which can, in part, be attributed to interannual variation. Soil $\mathrm{CO}_{2}$ fluxes at Gigante varied by more than $3 \mathrm{Mg} \mathrm{Cha}^{-1} \mathrm{yr}^{-1}$ between 2006 and 2008 (Koehler et al., 2009a), and fine litterfall, one of the substrates of heterotrophic respiration, also varied by about $2 \mathrm{Mg} \mathrm{ha}^{-1} \mathrm{yr}^{-1}$ from 1998 to 2008 (with annual averages of 7.7-9.7 $\mathrm{Mg} \mathrm{ha}^{-1} \mathrm{yr}^{-1}$; Wright et al., 2011). Moreover, our values were comparable with those of a mature secondary forest (P15 site; 7-18 Mg Cha ${ }^{-1} \mathrm{yr}^{-1}$ in 2007-2008; Notthingham et al., 2010) close to our P8 and P19 sites (Fig. S1). Finally, three of our sites (Met, P27 and P19) were mature secondary forests, with tree densities (particularly at Met and P27; see Sect. 2.1) lower than the old-growth forests on BCI (Pyke et al., 2001) and Gigante (Koehler et al., 2009a). This may have additionally influenced soil $\mathrm{CO}_{2}$ fluxes since up to $35 \%$ of $\mathrm{CO}_{2}$ emissions can be contributed by root respiration (Silver et al., 2005). Interestingly, regardless of the contribution of autotrophic respiration to soil $\mathrm{CO}_{2}$ fluxes, we did not detect any significant differences in soil $\mathrm{CO}_{2}$ fluxes among sites. We only found that across our five sites the temporal pattern of soil $\mathrm{CO}_{2}$ fluxes was strongly related to soil moisture.

Net soil $\mathrm{CO}_{2}$ emissions responded to changes in climatic factors on a seasonal scale (i.e., higher soil $\mathrm{CO}_{2}$ fluxes in the wet than the dry season at all sites; Table 3) and to daily fluctuations in soil temperature and moisture across the five sites (see Sect. 3.2). The hierarchy of importance for the soilcontrolling factors is shown in Table S1: at each site (except P27) and during the dry season across sites, soil moisture was the most important driving factor, followed by soil temperature, $\mathrm{NH}_{4}^{+}$or $\mathrm{NO}_{3}^{-}$. During the wet season when soil moisture was sufficient, the most important soil factors were $\mathrm{NH}_{4}^{+}$and soil temperature (Table S1). The higher $\mathrm{CO}_{2}$ emissions in the wet season were likely due to the alleviation of water competition between decomposers and vegetation; in seasonal tropical forests, litter tends to fall in the dry season, but low soil moisture limits decomposition until the start of the wet season (Yavitt et al., 2004). Other studies from CSA lowland forests have also reported a positive relationship between soil $\mathrm{CO}_{2}$ emissions and soil temperature (Chambers et al., 2004; Schwendenmann and Veldkamp, 2006; Sotta et al., 2006; Koehler et al., 2009a), and parabolic relationships (Fig. 3) between soil $\mathrm{CO}_{2}$ emissions and soil moisture (Schwendenmann et al., 2003; Sotta et al., 2006; Koehler et al., 2009a). Additionally, soil $\mathrm{CO}_{2}$ emissions responded to changes in soil mineral $\mathrm{N}$ both on the plot level and across sites (see Sect. 3.2). Relationships between soil $\mathrm{CO}_{2}$ emissions and soil mineral $\mathrm{N}$ concentrations have not been reported in other studies, although Schwendenmann et al. (2003) observed that spatial differences in soil total $\mathrm{N}$ were positively correlated with soil $\mathrm{CO}_{2}$ fluxes, and Koehler et al. (2009a) found that chronic $\mathrm{N}$ addition decreased soil $\mathrm{CO}_{2}$ fluxes in a montane tropical forest (although not in a lowland forest). However, the correlations between $\mathrm{CO}_{2}$ emissions and both $\mathrm{NH}_{4}^{+}$(positive correlation) and $\mathrm{NO}_{3}^{-}$(negative correlation) may also simply reflect a cocorrelation between extractable mineral $\mathrm{N}$ and soil moisture (see Sect. 3.2).

In support of our hypothesis, we observed that annual soil $\mathrm{CO}_{2}$ fluxes exhibited a parabolic pattern along the precipitation gradient (Table 4) similar to the relationship seen with the daily emissions and soil moisture (Fig. 3). However, as mentioned above, soil $\mathrm{CO}_{2}$ efflux did not differ among the five forest sites of this precipitation gradient (Table 3). This lack of differences between sites could be due to similarity in soil-controlling factors that results in comparably low soil $\mathrm{CO}_{2}$ emissions at all sites. For example, although organic $\mathrm{C}$ and total $\mathrm{N}$ differed between sites, the soil $\mathrm{C}: \mathrm{N}$ ratios were comparable along these orthogonal gradients of annual precipitation and soil fertility (Table 2), suggesting that the bioavailability of soil organic matter for heterotrophic respiration may be similar across sites. Additionally, the microbial communities that contribute to heterotrophic respiration may have adapted to the existing differences in substrate quantity (e.g., soil organic C), soil and climatic characteristics between the sites (Tables 2 and 3) and therefore exhibited an overall similar soil $\mathrm{CO}_{2}$ efflux.

\section{2 $\mathrm{CH}_{4}$ fluxes}

Our findings show the scale dependency of environmental controls on soil $\mathrm{CH}_{4}$ fluxes; the short-term (seasonal) patterns within and across sites were dominantly controlled by soil moisture, temperature and mineral N (Table S1), whereas the long-term pattern based on annual fluxes across sites was largely controlled by soil fertility (Fig. 4b).

The control of soil moisture on soil $\mathrm{CH}_{4}$ fluxes has been shown in several CSA tropical forest studies (Keller and 
Reiners, 1994; Verchot et al., 2000; Davidson et al., 2004; Veldkamp et al., 2013). This was also observed at our sites, with less $\mathrm{CH}_{4}$ uptake during periods of high water content (i.e., wet vs. dry season; Table 3). Soil moisture was the dominant controlling factor at each site (except Met) and across sites during each season (Table S1), and there was a positive correlation between soil $\mathrm{CH}_{4}$ fluxes and water content (Fig. 4a). We attribute the dominant role of soil moisture to controlling gas diffusivity from the atmosphere into the soil and/or methanogenic activity during periods of high moisture. Our annual soil $\mathrm{CH}_{4}$ uptake (Table 4) was within the range of other reported values from Brazil and Panama (Verchot et al., 2000; Davidson et al., 2004; Keller et al., 2005; Silver et al., 2005; Veldkamp et al., 2013). Studies that have measured a stronger uptake in CSA lowland forests (up to $4.90 \mathrm{~kg} \mathrm{Cha}^{-1} \mathrm{yr}^{-1}$; Keller and Reiners, 1994; Steudler et al., 1996; Keller et al., 2005; Sousa Neto et al., 2011) may have had soils with higher gas diffusivity due to lower soil water content and/or lower clay content (see Veldkamp et al., 2013); in our five sites, the two sites with the highest sand content (P8 and P19; Table 1) exhibited the highest soil $\mathrm{CH}_{4}$ uptake (Tables 3 and 4). In addition to moisture, soil $\mathrm{NO}_{3}^{-}$may have also been an important driver of temporal soil $\mathrm{CH}_{4}$ uptake in our sites; we observed increased $\mathrm{CH}_{4}$ uptake as $\mathrm{NO}_{3}^{-}$concentrations increased in P8, P19 and P32 (see Sect. 3.3), and it was a dominant controlling factor across sites in both seasons (Table S1). Although this may have reflected a co-correlation between soil $\mathrm{NO}_{3}^{-}$concentration and soil moisture (see Sect. 3.1), increasing $\mathrm{CH}_{4}$ uptake in the soil with increasing mineral $\mathrm{N}$ has been observed in the tropical forest soils of Australia (Kiese et al., 2003), Panama (Veldkamp et al., 2013) and Indonesia (Hassler et al., 2013). Additionally, our soils exhibited a correlation between annual soil $\mathrm{CH}_{4}$ fluxes and soil ${ }^{15} \mathrm{~N}$ natural abundance signatures (Table 5), the latter being an indicator of soil $\mathrm{N}$ availability (Sotta et al., 2008; Arnold et al., 2009; Baldos et al., 2015). When separated by season, the correlation between soil $\mathrm{CH}_{4}$ fluxes and soil ${ }^{15} \mathrm{~N}$ natural abundance was stronger in the dry season than the wet season (Table S2), supporting our claim that soil $\mathrm{N}$ availability enhanced $\mathrm{CH}_{4}$ uptake in soils when gas diffusion was favorable (dry season).

The control of soil fertility on the long-term pattern of soil $\mathrm{CH}_{4}$ fluxes across sites was depicted by a correlation between annual soil $\mathrm{CH}_{4}$ fluxes and our calculated soil fertility index (Fig. 4b), which exhibited an opposite pattern to that of annual precipitation (Fig. S2). This soil fertility control was supported by the strong correlations of both annual (Table 5) and seasonal (Table S2) soil $\mathrm{CH}_{4}$ fluxes with ECEC and exchangeable $\mathrm{Al}$, both included in the soil fertility index (Fig. S2; see Sect. 2.4). The correlations between soil $\mathrm{CH}_{4}$ fluxes and fertility indicators reflected the site differences in soil biochemical characteristics (Table 2). Specifically, as shown by the strong inverse correlation between soil $\delta^{15} \mathrm{~N}$ natural abundance signatures and exchangeable cations (Table 5), the positive correlation between soil $\mathrm{CH}_{4}$ flux and fertility (Fig. 4b) likely reflected the long-term effects of soil development (Tables 1 and 2). More $\mathrm{CH}_{4}$ uptake occurred in highly weathered soils with fewer rock-derived nutrients but high soil $\mathrm{N}$ availability (i.e., high $\delta^{15} \mathrm{~N}$ natural abundance signatures; Tables 4 and 5). This supports our hypothesis that soil $\mathrm{CH}_{4}$ uptake reflected the control of soil moisture and $\mathrm{N}$ availability across sites along this precipitation gradient. Our results also highlight the importance of considering soil properties, in particular the degree of soil development, rather than simply climatic factors when predicting and modeling soil $\mathrm{CH}_{4}$ fluxes on a large scale.

\section{3 $\quad \mathrm{N}_{2} \mathrm{O}$ fluxes}

Our annual soil $\mathrm{N}_{2} \mathrm{O}$ fluxes (Table 4) were within the lower end of the range (1.23-11.4 $\left.\mathrm{kg} \mathrm{Nha}^{-1} \mathrm{yr}^{-1}\right)$ reported by other CSA forest studies (Keller and Reiners, 1994; Verchot et al., 1999; Keller et al., 2005; Silver et al., 2005). In comparison with other studies from Panama, our $\mathrm{N}_{2} \mathrm{O}$ fluxes were similar to those measured from Gigante during dry years $\left(0.5 \pm 0.2 \mathrm{~kg} \mathrm{Nha}^{-1} \mathrm{yr}^{-1}\right.$ in 2008-2009 with annual precipitation 5-26\% lower than the 12-year average; Corre et al., 2014) but slightly lower than those measured from the same site during wet years $\left(1.0-1.4 \mathrm{~kg} \mathrm{~N} \mathrm{ha}^{-1} \mathrm{yr}^{-1}\right.$ in 2006-2007 with annual precipitation 5-17\% higher than the 12-year average; Koehler et al., 2009b). The low soil $\mathrm{N}_{2} \mathrm{O}$ fluxes at our sites were likely caused by the generally lower soil $\mathrm{N}$ availability compared to the Gigante site; the five sites in our present study had an average gross $\mathrm{N}$ mineralization rate of $4 \pm 1 \mathrm{mg} \mathrm{N} \mathrm{kg}^{-1} \mathrm{~d}^{-1}$ in the 2010 wet season (Corre et al., unpublished data), which was significantly lower than the rates from Gigante $\left(29 \pm 6 \mathrm{mg} \mathrm{N} \mathrm{kg}^{-1} \mathrm{~d}^{-1}\right.$ in the 2006 wet season; Corre et al., 2010).

Interannual variation in rainfall and hence soil moisture can also strongly affect soil $\mathrm{N}_{2} \mathrm{O}$ emissions (Corre et al., 2014). Our measured soil $\mathrm{N}_{2} \mathrm{O}$ emissions exhibited a tendency to be higher in the wet season than the dry season (P8 and P19; Table 3). They were the highest at the mid-rainfall site P8 (which could mean that at the high-rainfall sites $\mathrm{N}_{2} \mathrm{O}$ is further denitrified to $\mathrm{N}_{2}$ ) and were only correlated with the soil ${ }^{15} \mathrm{~N}$ natural abundance signatures (as an indicator of soil $\mathrm{N}$ availability) in the wet season (Table S2). At the sites (P8 and $\mathrm{P} 19$ ) where $\mathrm{N}_{2} \mathrm{O}$ emissions were higher in the wet than the dry season and soil $\mathrm{NO}_{3}^{-}$levels were lower in the wet than the dry season (Table 3), the inverse correlation between daily soil $\mathrm{N}_{2} \mathrm{O}$ emissions and $\mathrm{NO}_{3}^{-}$concentrations over the 21-month measurement period suggests that during the wet season $\mathrm{N}_{2} \mathrm{O}$ production could have been high but might have been further denitrified to $\mathrm{N}_{2}$, hence resulting in low soil $\mathrm{NO}_{3}^{-}$concentrations. Although the reduction of $\mathrm{NO}_{3}^{-}$in the wet season could also be caused by reduced nitrification, the measurements in our study area (once in the wet and once in the dry season) showed no significant differences between the wet and dry seasons across sites or at each site (Corre et al., unpublished data). Additionally, gross nitrification was 
correlated with $\mathrm{NO}_{3}^{-}$immobilization, but not with DNRA, suggesting that when there was high $\mathrm{NO}_{3}^{-}$availability, this was preferably assimilated by the microbial biomass (Corre et al., unpublished data). On the other hand, the soil $\mathrm{NO}_{3}^{-}$levels we show in Table 3 were measured repeatedly, parallel to soil trace gas flux measurements, over our 21-month study period. The soil $\mathrm{NO}_{3}^{-}$levels (Table 3) therefore reflected the concurrently occurring $\mathrm{NO}_{3}^{-}$production and consumption processes. The argument that these reflect further denitrification to $\mathrm{N}_{2}$ is supported by our earlier study in Gigante, in which nitrification and denitrification contributed equally to soil $\mathrm{N}_{2} \mathrm{O}$ emissions during the dry season, but denitrification was the main process contributing to soil $\mathrm{N}_{2} \mathrm{O}$ emission in the wet season (Koehler et al., 2012; Corre et al., 2014). Our results partly supported our initial hypothesis that soil $\mathrm{N}_{2} \mathrm{O}$ emissions were the highest at the mid-precipitation site (with the highest soil $\mathrm{N}$ availability as indicated by ${ }^{15} \mathrm{~N}$ natural abundance; Table 2) due to the possible reduction of $\mathrm{N}_{2} \mathrm{O}$ to $\mathrm{N}_{2}$ at the high-precipitation site.

\subsection{NO fluxes}

Our annual soil NO fluxes (Table 4) were considerably lower than other reported NO fluxes, which are usually small net emissions rather than net uptake. Soil NO emissions from Panama, Costa Rica and Brazil range from 0.26 to $7.88 \mathrm{~kg}$ $\mathrm{N} \mathrm{ha}^{-1} \mathrm{yr}^{-1}$ (Keller and Reiners, 1994; Verchot et al., 1999; Gut et al., 2002; Keller et al., 2005; Silver et al., 2005; Koehler et al., 2009b; Corre et al., 2014). However, the net negative NO fluxes that we measured may reflect unusually high ambient air NO concentrations in our forest sites compared to forests from other studies. Although all of our sites were located in mature secondary or old-growth forests, the forests were located within the Panama Canal watershed where there is heavy year-round marine traffic $(\sim 13000$ cargo ships in 2011; Hricko, 2012). Furthermore, the highest levels of net negative NO fluxes that we measured were in the Met site (Table 4); in addition to being in the vicinity of the Panama Canal, the park is located within the city limits of Panama City, which has a population of approximately 1.6 million (The World Factbook, 2015). Therefore, elevated ambient air NO concentrations from anthropogenic emissions may be driving the net negative NO fluxes that we measured. Our instrument cannot measure $\mathrm{O}_{3}$ concentration, which could be high in these sites influenced by anthropogenic emissions. Thus, the net negative NO fluxes that we observed may have been driven by both chemical reactions (deposition onto the soil within the chamber through the reaction of ambient $\mathrm{NO}$ with ambient $\mathrm{O}_{3}$; Pape et al., 2009) and microbiological processes (NO consumption in the soil as an intermediate product of nitrification and denitrification; Davidson et al., 2000). The reaction time of NO with $\mathrm{O}_{3}$, which is then subsequently removed from the enclosed chamber air and deposited onto the soil, is controlled by the ambient air NO concentrations (Pape et al., 2009). It is no- table that an earlier study in Gigante, which is also part of the Panama Canal watershed, did not show negative NO fluxes but instead small net NO emissions (Koehler et al., 2009b; Corre et al., 2014). However, as mentioned above, the Gigante site had higher soil N-cycling rates (Corre et al., 2010) and lower ambient air NO concentrations than our sites, such that $\mathrm{NO}$ production in the soil may have compensated for the chemical reaction of ambient $\mathrm{NO}$ with $\mathrm{O}_{3}$ and thus resulted in net soil NO emissions. Contrary to this, the negative correlation of soil NO fluxes with ambient NO concentrations observed in our sites (i.e., net negative NO flux increased as ambient air NO concentration increased; Fig. 5) suggests that NO production in the soil was overshadowed by the chemical reaction of ambient $\mathrm{NO}$ with $\mathrm{O}_{3}$ and thus resulted in net negative NO fluxes.

The general trend across sites did not support our hypothesis regarding soil NO emission, since local conditions of high ambient NO concentrations in the atmosphere had an overriding effect, resulting in net NO uptake in soils (Fig. 2d). However, our results indicated that our soils could also be a net source of $\mathrm{NO}$ when soil conditions were favorable and/or ambient air NO concentrations were not elevated. We observed that net NO uptake was consistently higher in the wet season than the dry season (Table 3); in the dry season, when aerobic soil conditions prevailed due to low soil moisture contents (Table 3 ), NO production in the soil may have been more favored (Conrad, 2002), partly counteracting the chemical reaction of NO removal from the atmosphere and its deposition onto the soil. This is also supported by the negative correlation between dry season soil NO fluxes and clay contents of the sites (Table S2), suggesting that soil NO fluxes responded to conditions favorable for NO production. Favorable soil conditions were most visible at $\mathrm{P} 8$, which had the highest soil NO emissions (with low ambient air NO concentrations) in the dry season (Table 3; Fig. 2d); soil NO fluxes at this site increased when aerobic soil conditions prevailed (i.e., negative correlation with soil moisture; see Sect. 3.5) and increased with substrate availability (i.e., positive correlation with soil $\mathrm{NO}_{3}^{-}$; see Sect. 3.5).

In summary, although the soils in our study sites can be a net source of NO, particularly during the dry season (Fig. 2d) and in sites where ambient air NO concentrations were low (Fig. 5), most of the time the soils acted as a net sink of NO, signifying the importance of soil and vegetation as NO sinks (Jacob and Bakwin, 1991; Sparks et al., 2001) in areas affected by anthropogenic NO sources.

\subsection{Implications for climate change}

It is notable that, although all four trace gases were strongly correlated with the temporal variation in soil moisture and had clear differences between seasons (Table 3), there were no correlations between the four soil trace gases when looking at the annual fluxes (Table 5) or seasonal averages (Table S2). This lack of correlation may be due to the interaction 
of other soil and climatic factors with known drivers of soil trace gas production and consumption. It may also reflect the fact that trace gas fluxes at the soil surface are the net result of gross production and consumption processes occurring belowground where correlations may exist. Future research might consider including an analysis of the abundance and activity of functional microbial groups along gradients of precipitation and fertility to better understand relationships between the different trace gases.

We have shown that in the short term, soil trace gas fluxes were largely controlled by soil moisture with the additional influences of soil temperature and mineral $\mathrm{N}$ concentration. However, in the long term and/or over large spatial scales, the degree of soil development and related soil fertility had a strong influence. Additionally, we have shown that even in presently undisturbed forests, gas fluxes can be affected by "upstream" anthropogenic activities. Therefore, in order to understand and predict soil trace gas fluxes under future climate scenarios, research needs to focus on identifying and predicting the interacting effects of soils and sites as well as climatic characteristics on soil-atmosphere trace gas exchange.

Data availability. Data available from the Dryad Digital Repository: Soil trace gas fluxes along orthogonal precipitation and soil fertility gradients in tropical lowland forests of Panama (http://dx. doi.org/10.5061/dryad.8812m).

\section{The Supplement related to this article is available online at https://doi.org/10.5194/bg-14-3509-2017-supplement.}

Competing interests. The authors declare that they have no conflict of interest.

Acknowledgements. Funding for this study was provided by the Deutsche Forschungsgemeinschaft (DFG, Co 749/1-1) and by the Robert Bosch Foundation (Germany) for Marife D. Corre's independent research group, NITROF. We gratefully acknowledge Helene Muller-Landau for hosting us and facilitating access to the field sites. The Smithsonian Tropical Research Institute and ANAM Panama provided invaluable administrative and technical support. The efforts of the NITROF assistants (Rodolfo Rojas and Erick Diaz) and the SSTSE laboratory technicians in completing the data collection and analyses are much appreciated.

This open-access publication was funded by the University of Göttingen.

Edited by: Ivonne Trebs

Reviewed by: two anonymous referees

\section{References}

Allen, K., Corre, M. D., Tjoa, A., and Veldkamp, E.: Soil nitrogencycling responses to conversion of lowland forests to oil palm and rubber plantations in Sumatra, Indonesia, PLoS ONE, 10, e0133325, https://doi.org/10.1371/journal.pone.0133325, 2015.

Baldos, A. P., Corre, M. D., and Veldkamp, E.: Response of N cycling to nutrient inputs in forest soils across a 1000-3000 m elevation gradient in the Ecuadorian Andes, Ecology, 96, 749-761, 2015.

Bouwman, A. F., Fung, I., Matthews, E., and John, J.: Global analysis of the potential for $\mathrm{N}_{2} \mathrm{O}$ production in natural soils, Global Biogeochem. Cy., 7, 557-597, 1993.

Butterbach-Bahl, K., Baggs, E. M., Dannenmann, M., Kiese, R., and Zechmeister-Boltenstern, S.: Nitrous oxide emissions from soils: how well do we understand the processes and their controls?, Phil. Trans. R. Soc., 368, 20130122, https://doi.org/10.1098/rstb.2013.0122, 2013.

Chambers, J. Q., Tibuzy, E. S., Toledo, L. C., Crispim, B. F., Iguchi, N., dos Santos, J., Araujo, A. C., Kruijt, B., Nobre, A. D., and Trumbore, S. E.: Respiration from a tropical forest ecosystem: partitioning of sources and low carbon use efficiency, Ecol. Appl., 14, S72-S88, 2004.

Chameides, W. L., Fehsenfeld, F., and Rodgers, M. O.: Ozone precursor relationships in the ambient atmosphere, J. Geophys. Res., 97, 6037-6055, 1992.

Chapuis-Lardy, L. Y. D. I. E., Wrage, N., Metay, A., Chotte, J. L., and Bernoux, M.: Soils, a sink for $\mathrm{N}_{2} \mathrm{O}$ ? A review, Glob. Change Biol., 13, 1-17, 2007.

Chin, K. J., Lukow, T., and Conrad, R.: Effect of temperature on structure and function of the methanogenic archaeal community in an anoxic rice field soil, Appl. Environ. Microbiol., 65, 23412349, 1999.

Conrad, R.: Soil microorganisms as controllers of atmospheric trace gases $\left(\mathrm{H}_{2}, \mathrm{CO}, \mathrm{CH}_{4}, \mathrm{OCS}, \mathrm{N}_{2} \mathrm{O}\right.$, and $\left.\mathrm{NO}\right)$, Microbiol. Rev., 60, 609-640, 1996.

Conrad, R.: Microbiological and biochemical background of production and consumption of $\mathrm{NO}$ and $\mathrm{N}_{2} \mathrm{O}$ in soil, in: Trace Gas Exchange in Forest Ecosystems, edited by: Gasche, R., Papen, H., and Rennenberg, H., Dordrecht, Kluwer Academic Publishers, 3-33, 2002.

Corre, M. D., Veldkamp, E., Arnold, J., and Wright, S. J.: Impact of elevated $\mathrm{N}$ input on soil $\mathrm{N}$ cycling and losses in old-growth lowland and montane forests in Panama, Ecology, 91, 1715-1729, 2010.

Corre, M. D., Sueta, J. P., and Veldkamp, E.: Nitrogen-oxide emissions from tropical forest soils exposed to elevated nitrogen input strongly interact with rainfall quantity and seasonality, Biogeochemistry, 118, 103-120, 2014.

Crawley, M. J.: The R book, Chichester, John Wiley, 2012.

Davidson, E. A. and Schimel, J. P.: Microbial processes of production and consumption of nitric oxide, nitrous oxide and methane, in: Biogenic trace gases: measuring emissions from soil and water, edited by: Matson, P. A. and Harriss, R. C., Blackwell Science, Oxford, 327-357, 1995.

Davidson, E. A., Verchot, L. V., Cattânio, J. H., Ackerman, I. L., and Carvalho, J. E. M.: Effects of soil water content on soil respiration in forests and cattle pastures of eastern Amazonia, Biogeochemistry, 48, 53-69, 2000. 
Davidson, E. A., Yoko Ishida, F., and Nepstad, D. C.: Effects of an experimental drought on soil emissions of carbon dioxide, methane, nitrous oxide, and nitric oxide in a moist tropical forest, Glob. Change Biol., 10, 718-730, https://doi.org/10.1111/j.15298817.2003.00762.x, 2004.

Dryad Digital Repository: Soil trace gas fluxes along orthogonal precipitation and soil fertility gradients in roical lowland forests of Panama (http://dx.doi.org/10.5061/dryad.8812m).

Engelbrecht, B. M., Comita, L. S., Condit, R., Kursar, T. A., Tyree, M. T., Turner, B. L., and Hubbell, S. P.: Drought sensitivity shapes species distribution patterns in tropical forests, Nature, 447, 80-82, 2007.

Gut, A., van Dijk, S. M., Scheibe, M., Rummel, U., Welling, M., Ammann, C., Meixner, F. X., Kirkman, G. A., Andreae, M. O., and Lehmann, B. E.: NO emission from an Amazonian rain forest soil: Continuous measurements of NO flux and soil concentration, J. Geophys. Res., 107, 8057, https://doi.org/10.1029/2001JD000521, 2002.

Hanson, P. J., Edwards, N. T., Garten, C. T., and Andrews, J. A.: Separating root and soil microbial contributions to soil respiration: a review of methods and observations, Biogeochemistry, 48, 115-146, 2000.

Hassler, E., Corre, M. D., Tjoa, A., Damris, M., Utami, S. R., and Veldkamp, E.: Soil fertility controls soil-atmosphere carbon dioxide and methane fluxes in a tropical landscape converted from lowland forest to rubber and oil palm plantations, Biogeosciences, 12, 5831-5852, https://doi.org/10.5194/bg-125831-2015, 2015.

Holtgrieve, G. W., Jewett, P. K., and Matson, P. A.: Variations in soil $\mathrm{N}$ cycling and trace gas emissions in wet tropical forests, Oecologia, 146, 584-594, 2006.

Hricko, A.: Progress and pollution: port cities prepare for the Panama Canal expansion, Environ. Health Persp., 120, A470 32012, 2012.

Jacob, D. and Bakwin, P.: Cycling of $\mathrm{NO}_{x}$ in tropical forest canopies, in: Microbial production and consumption of greenhouse gases: methane, nitrogen oxides and halomethanes, edited by: Rogers, J. E. and Whitman, W. B., American Society for Microbiology, Washington, DC, USA, 237-253, 1991.

Jenny, H.: Arrangement of soil series and types according to functions of soil-forming factors, Soil Sci., 61, 375-392, 1946.

Keller, M. and Reiners, W. A.: Soil-atmosphere exchange of nitrous oxide, nitric oxide, and methane under secondary succession of pasture to forest in the Atlantic lowlands of Costa Rica, Global Biogeochem. Cy., 8, 399-409, 1994.

Keller, M., Jacob, D. J., Wofsy S. C., and Harriss, R. C.: Effects of tropical deforestation on global and regional atmospheric chemistry, Climate Change, 19, 139-158, 1991.

Keller, M., Varner, R., Dias, J. D., Silva, H., Crill, P., de Oliveira, R. C., and Asner, G. P.: Soil-atmosphere exchange of nitrous oxide, nitric oxide, methane, and carbon dioxide in logged and undisturbed forest in the Tapajos national forest, Brazil, Earth Interact., 9, 1-28, 2005.

Kiese, R., Hewett, B., Graham, A., and Butterbach-Bahl, K.: Seasonal variability of $\mathrm{N}_{2} \mathrm{O}$ and $\mathrm{CH}_{4}$ uptake by tropical rainforest soils of Queensland, Australia, Global Biogeochem. Cy., 25, 1043, https://doi.org/10.1029/2002GB002014, 2003.

Koehler, B., Corre, M. D., Veldkamp, E., and Sueta, J. P.: Chronic nitrogen addition causes a reduction in soil carbon dioxide efflux during the high stem-growth period in a tropical montane forest but no response from a tropical lowland forest on a decadal time scale, Biogeosciences, 6, 2973-2983, https://doi.org/10.5194/bg6-2973-2009, 2009a.

Koehler, B., Corre, M. D., Veldkamp, E., Wullaert, H., and Wright, S. J.: Immediate and long-term nitrogen oxide emissions from tropical forest soils exposed to elevated nitrogen input, Glob. Change Biol., 15, 2049-2066, 2009b.

Koehler, B., Zehe, E., Corre, M. D., and Veldkamp, E.: An inverse analysis reveals limitations of the soil- $\mathrm{CO}_{2}$ profile method to calculate $\mathrm{CO}_{2}$ production and efflux for well-structured soils, Biogeosciences, 7, 2311-2325, https://doi.org/10.5194/bg-7-23112010, 2010.

Koehler, B., Corre, M. D., Steger, K., Well, R., Zehe, E., Sueta, J. P., and Veldkamp, E.: An in-depth look into a tropical lowland forest soil: how 9-11 years experimental nitrogen addition affected the contents of $\mathrm{N}_{2} \mathrm{O}, \mathrm{CO}_{2}$ and $\mathrm{CH}_{4}$ down to 2-m depth, Biogeochemistry, 111, 695-713, 2012.

König, N. and Fortmann, H.: Probenvorbereitungs-, Untersuchungs und Elementbestimmungs-Methoden des UmweltanalytikLabors der Niedersächsischen Forstlichen Versuchsanstalt, Berichtedes Forschungszentrums Waldökosysteme, Reihe B, University of Göttingen, 1-4, 1996.

Kursar, T. A.: Evaluation of soil respiration and soil $\mathrm{CO}_{2}$ concentration in a lowland moist forest in Panama, Plant Soil, 113, 21-29, 1989.

Le Mer, J. and Roger, P.: Production, oxidation, emission and consumption of methane by soils: a review, Eur. J. Soil Biol., 37, 25-50, 2001.

Mariotti, A., Germon, J. C., Hubert, P., Kaiser, P., Letolle, R., Tardieux, A., and Tardieux, P.: Experimental determination of nitrogen kinetic isotope fractionation: some principles; illustration for the denitrification and nitrification processes, Plant Soil, 62, 413-430, 1981.

Mohanty, S. R., Bodelier, P. L. E., and Conrad, R.: Effect of temperature on composition of the methanotrophic community in rice field and forest soil, FEMS Microbiol. Ecol., 62, 24-31, 2007.

Nottingham, A. T., Turner, B. L., Winter, K., van der Heijden, M. G., and Tanner, E. V.: Arbuscular mycorrhizal mycelial respiration in a moist tropical forest, New Phytol., 186, 957-967, 2010.

Pape, L., Ammann, C., Nyfeler-Brunner, A., Spirig, C., Hens, K., and Meixner, F. X.: An automated dynamic chamber system for surface exchange measurement of non-reactive and reactive trace gases of grassland ecosystems, Biogeosciences, 6, 405429, https://doi.org/10.5194/bg-6-405-2009, 2009.

Prather, M., Derwent, R., Ehhalt, D., Fraser, P., Sanhueza, E., and Zhou, X.: Other trace gases and atmospheric chemistry, in: Climate Change 1994, edited by: Houghton, J. T., Meira Filho, L. G., Bruce, J., Lee, H., Callander, B. A., Haites, E., Harris, N., and Maskell, K., Cambridge University Press, Cambridge, UK, 73-126, 1995.

Pyke, C. R., Condit, R., Aguilar, S., and Lao, S.: Floristic composition across a climatic gradient in a neotropical lowland forest, J. Veg. Sci., 12, 553-566, 2001.

$\mathrm{R}$ Core Team R: A language and environment for statistical computing. R Foundation for Statistical Computing, Vienna, Austria, ISBN 3-900051-07-0, http://www.R-project.org (last access: 15 July 2017), 2013. 
Raich, J. W. and Schlesinger, W. H.: The global carbon dioxide flux in soil respiration and relationship to vegetation and climate, Tellus B, 44, 81-99, 1992.

Rummel, U., Ammann, C., Gut, A., Meixner, F. X., and Andreae, M. O.: Eddy covariance measurements of nitric oxide flux within an Amazonian rain forest, J. Geophys. Res., 107, 8050, https://doi.org/10.1029/2001JD000520, 2002

Saikawa, E., Schlosser, C. A., and Prinn, R. G.: Global modeling of soil nitrous oxide emissions from natural processes, Global Biogeochem. Сy., 27, 972-989, https://doi.org/10.1002/gbc.20087, 2013.

Santiago, L. S., Schuur, E. A., and Silvera, K.: Nutrient cycling and plant-soil feedbacks along a precipitation gradient in lowland Panama, J. Trop. Ecol., 21, 461-470, 2005.

Schwendenmann, L. and Veldkamp, E.: Long-term $\mathrm{CO}_{2}$ production from deeply weathered soils of a tropical rain forest: Evidence for a potential positive feedback to climate warming, Glob. Change Biol., 12, 1878-1893, 2006.

Schwendenmann, L., Veldkamp, E., Brenes, T., O'Brien J. J., and Mackensen, J.: Spatial and temporal variation in soil $\mathrm{CO}_{2}$ efflux in an old-growth neotropical rain forest, La Selva, Costa Rica, Biogeochemistry, 64, 111-128, 2003.

Silver, W. L., Neff, J., McGroddy, M., Veldkamp, E., Keller, M., and Cosme, R.: Effects of Soil Texture on Belowground Carbon and Nutrient Storage in a Lowland Amazonian Forest Ecosystem, Ecosystems, 3, 193-209. https://doi.org/10.1007/s100210000019, 2000.

Silver, W. L., Thompson, A. W., McGroddy, M. E., Varner, R. K., Dias, J. D., Silva, H., Crill, P. M., and Keller, M.: Fine root dynamics and trace gas fluxes in two lowland tropical forest soils, Glob. Change Biol., 11, 290-306, https://doi.org/10.1111/j.13652486.2005.00903.x, 2005.

Sotta, E. D., Veldkamp, E., Guimaraes, B. R., Paixao, R. K., Ruivo, M. L. P., and Almeida, S. S.: Landscape and climatic controls on spatial and temporal variation in soil $\mathrm{CO}_{2}$ efflux in an Eastern Amazonian Rainforest, Caxiuana, Brazil, Forest Ecol. Manage., 237, 57-64, 2006.

Sotta, E. D., Corre, M. D., and Veldkamp, E.: Differing N status and $\mathrm{N}$ retention processes of soils under old-growth lowland forest in Eastern Amazonia, Caxiuanã, Brazil, Soil Biol. Biochem., 40, 740-750, 2008.

Sousa Neto, E., Carmo, J. B., Keller, M., Martins, S. C., Alves, L. F., Vieira, S. A., Piccolo, M. C., Camargo, P., Couto, H. T. Z., Joly, C. A., and Martinelli, L. A.: Soil-atmosphere exchange of nitrous oxide, methane and carbon dioxide in a gradient of elevation in the coastal Brazilian Atlantic forest, Biogeosciences, 8, 733-742, https://doi.org/10.5194/bg-8-733-2011, 2011.

Sparks, J. P., Monson, R. K., Sparks, K. L., and Lerdau, M.: Leaf uptake of nitrogen dioxide $\left(\mathrm{NO}_{2}\right)$ in a tropical wet forest: Implications for tropospheric chemistry, Oecologia, 127, 214-221, https://doi.org/10.1007/s004420000594, 2001.
Steudler, P. A., Melillo, J. M., Feigl, B. J., Neill, C., Piccolo, M. C., and Cerri, C. C.: Consequences of forest-to-pasture conversion on $\mathrm{CH}_{4}$ fluxes in the Brazilian Amazon Basin, J. Geophys. Res.Atmos., 101, 18547-18554, https://doi.org/10.1029/96JD01551, 1996.

Stocker, T. F., Qin, D., Plattner, G. K., Tignor, M., Allen, S. K., Boschung, J., Nauels, A., Xia, Y., Bex, B., and Midgley, B. M.: IPCC, 2013: climate change 2013: the physical science basis. Contribution of working group I to the fifth assessment report of the intergovernmental panel on climate change, https://www.ipcc.ch/pdf/assessment-report/ar5/ wg1/WGIAR5_SPM_brochure_en.pdf (last access: 15 July 2017), 2013.

Swaine, M. D.: Rainfall and soil fertility as factors limiting forest species distributions in Ghana, J. Ecol., 84, 419-428, 1996.

The World Factbook: Central America and Caribbean: Panama, https://www.cia.gov/library/publications/the-world-factbook/ geos/pm.html, last access: March, 2015.

Townsend, A. R., Asner, G. P., and Cleveland, C. C.: The biogeochemical heterogeneity of tropical forests, Trends Ecol. Evol., 23, 424-431, 2008.

Turner, B. L. and Engelbrecht, B. M. J.: Soil organic phosphorus in lowland tropical rain forests, Biogeochemistry, 103, 295-315, 2011.

Veldkamp, E., Koehler, B., and Corre, M. D.: Indications of nitrogen-limited methane uptake in tropical forest soils, Biogeosciences, 10, 5367-5379, https://doi.org/10.5194/bg-10-53672013, 2013.

Verchot, L. V., Davidson, E. A., Cattânio, H., Ackerman, I. L., Erickson, H. E., and Keller, M.: Land use change and biogeochemical controls of nitrogen oxide emissions from soils in eastern Amazonia, Global Biogeochem. Cy., 13, 31-46, 1999.

Verchot, L. V., Davidson, E. A., Cattanio, J. H., and Ackerman, I. L.: Land-use change and biogeochemical controls of methane fluxes in soils of eastern Amazonia, Ecosystems, 3, 41-56, https://doi.org/10.1007/s100210000009, 2000.

Windsor, D. M.: Climate and moisture availability in a tropical forest, long term record for Barro Colorado Island, Panama, Smithson. Contrib. Earth Sci., 29, 1-145, 1990.

Wright, S. J., Yavitt, J. B., Wurzburger, N., Turner, B. L., Tanner, E. V., Sayer, E. J., Santiago, L. S., Kaspari, M., Hedin, L. O., Harms, K. E., Garcia, M. N., and Corre, M. D.: Potassium, phosphorus, or nitrogen limit root allocation, tree growth, or litter production in a lowland tropical forest, Ecology, 92, 1616-1625, 2011.

Yavitt, J. B., Wright, S. J., and Kelman Wieder, R.: Seasonal drought and dry-season irrigation influence leaf-litter nutrients and soil enzymes in a moist, lowland forest in Panama, Austral. Ecol., 29, 177-188, 2004.

Zuur, A. F., Ieno, E. N., Walker, N. J., Saveliev, A. A., and Smith, G. M.: Mixed effects models and extensions in ecology with R. Springer, New York, 2009. 